University of Louisville ThinkIR: The University of Louisville's Institutional Repository

Electronic Theses and Dissertations

1949

\title{
A study of the backgrounds and contributions of forty-four letter writers to the Louisville Courier Journal Point of view column.
}

Sidney A. Forsythe

University of Louisville

Follow this and additional works at: https://ir.library.louisville.edu/etd

Part of the Sociology Commons

\section{Recommended Citation}

Forsythe, Sidney A., "A study of the backgrounds and contributions of forty-four letter writers to the Louisville Courier Journal Point of view column." (1949). Electronic Theses and Dissertations. Paper 2365.

https://doi.org/10.18297/etd/2365

This Master's Thesis is brought to you for free and open access by ThinkIR: The University of Louisville's Institutional Repository. It has been accepted for inclusion in Electronic Theses and Dissertations by an authorized administrator of ThinkIR: The University of Louisville's Institutional Repository. This title appears here courtesy of the author, who has retained all other copyrights. For more information, please contact thinkir@louisville.edu. 
UNIVERSITY OF LOUISVILLE

A STUDY OF THE BACKGROUNDS AND CONTRIBUTIONS OF FORTY-FOUR LETTER WRITERS TO THE LOUISVIILE

COURIER JOURNAL "POINT OF VIEW" COLUMN

\author{
A Dissertation \\ Submitted to the Faculty \\ Of the Graduate School of the University of Louisville \\ In Partial Fulfillment of the \\ Requirements for the Degree \\ Of Master of Arts
}

Department of Sociology

By

Sidney A. Forsythe

Year

1949 
NATE OF STUDEIT:

TITIE OF TIESIS: A Study of the Backgrounds and Contributions of

Forty-Four Letter Writers to the Louisville Courier Journal "Point of View" Column

APPROVED BY READING COLITTTEE COIPOSED OF THT

BOLLONITG HOMBERS:

Robert I. Kutak

R. L. Birdwhistell

Richard M. Kain

NAINS OF DIRECTOR:

Robert I. Kutak

DATE: 
Acknowledgments

The writer is grateful for the assistance given him by Mr. Barry Bullock of the Louisville Courier Journal staff, in discussing his project with him and affording him access to the Courier Journal library. He would like to acknowledge, gratefully, the prompt and careful filling-out of the questionnaire used in this study, by the forty-four letter writers whose backgrounds and letters formed the basis of this thesis.

For reading and criticizing the thesis, the writer is indebted to Dr. Eve Golson of the Department of English at Alabama College. For providing valuable guidance, in the preparation of the thesis, the author wishes to acknowledge the efforts of Mr. Birdwhistell and Dr. Robert I. Kutak of the Department of Sociology at the University of Louisville. 
Contents

Acknowledgments

Chapter I. Introductory

Chapter II. The Loulsville Courier Journal "Point of View" Column.

1. Statement of Policy concerning the Acceptance, Rejection and Fditing of Letters.

2. The Courier Journal Policy and the Polleles of Twelve other Major Dallies with respect to Reader Letters.

Chapter III. The Louisville Courier Journal "Point of View" Letter Friter.

1. Personal Data and Summarizations.

A. The ages of letter writers.

B. The occupations of letter writers.

C. Letter writers and church affiliation and preference.

D. Letter witers and political party affiliation and preference.

B. The formel education of letter writers.

F. The marital statuses of letter writers.

G. The nationelities of letter writers.

H. The place and length of residence of letter writers.

2. The Personal Activity of Letter Writers with respect to Media other then "Point of view."

A. Personal contact and activity in behalf of ideas expressed in "Point of View."

B. Publication in media other than the Courier Journsl "Point of View" column.

3. The Reading Habits of "Point of View" Letter Writers.

A. Newspapers.

B. Magazines.

C. Fiction (Books).

D. Hon-fiction (Books).

4. Why Do Letter Writers Write?

5. Summarization and breakdown by Groups of letters by field and most popular topies.

6. Groups I and II and the Most Popular Letter Topics

for the Period, June 1, 1946 - Uay 31, 1947.

A. Soviet Russia and Communism.

B. The New Deal.

C. OPA - The Cost of Iiving.

D. Organized Iabor.

E. Drinking and Gambling. 51

F. Comment 
Tables

I. The Occupational Croup Categories of Letter Writers.

II. The Denominational Affiliations or Preferences of Letter Friters. 15

III. The Marital Statuses of Letter Friters.

IV. Percenteges of Letter Writers Who Discuss Letters with Those Tho Do Not Frite.

V. Percentages of Letter Writers Tho Discuss Letters with Other Writers.

VI. Percentages of Letter Writers Tho Encourage Friends to Write.

VII. Percentages of Letter Writers Who Were Encouraged to Write by Others.

VII. Percentages of Letter Friters Tho Have Published in Media Other Than the "Point of View" Column.

IX. Other Publications of Letter Writers.

X. Letter Writer Opinions as to Whether Letters Are Bffective or Not.

XI. The Interests of Letter Writers According to Field.

XII. Individual Friter Concentrations on Favorite Topics.

XIII. Percentages of Letters Written on the Farorite Topics of the Writers.

XIV. Letter Friters and Their Writing Frequencies for June 1, 1946 May 31, 1947.

XV. Age-Group, Occupation, and Church Affiliation or Preference of Letter Friters.

XVI. Political Party Affiliation or Preference, Formal Education, and Marital status of Letter Writers.

XVII. Nationality, ResIdence, and Length of Residence of Letter Writers. 71

XVIII. Magazines Reed by Letter Friters. 72,73

XIX. Fiction (books) Readings of Letter Writers. 74, 75

Xx. Non-fiction (books) Rerdings. $76,77,78$

XXI. Distribution by Field and by Topic of the Letters Fritten by Forty-four Friters - June 1, 1946 - May 31, 1947. (with note, with respect to classification) 
Chapter I

Int roduct ory 
The purpose of this thesis on the Louisville Courler Journal "Point or Viern calum is to investigate the backgrounds and letters of some frequent and sone "chronic" letter writers.

It was declded that first it would be necessary to establish which persons wrote most often to the letter column. This was done by consulting the editor-in-charge of the colum at the Courier Journal and by checicing the names he supplied by an examination of the "Point of View columns from June 1, 1946 through Yay $31,1947$.

Frequency rates rere established for those with the highest rates of participation and the original group of forty-four was broken down into Group I (participating with the rates of 11-23 letters for the period studied), Group II (participating at the rates of 6-10), and Group III (participating with the rates of 1-5 letters for the year). The persons in these three groups are designated "very frequent" or "chronic," "frequent," and "moderate" letter miters, respectively.

By comparing these three groups it was hoped that perspective might be gained on Groups I and II which constitute the special problem of this paper.

It was assumed by the writer that the personal date significant for a study of this sort could be easily obtained from those who wrote often to the letter column and that these persons might express themselves more freely than those who were accustomed to writing very occasically. It was also believed that these writ ers were more significant subjects since they probably had wider and more attentive audiences than those whose letters appeared infrequently. 
Forty of the fiftymive questionnaires sent to the writers at the beginning of this study (August 1, 1947) were returned within several months. Follon-ap questionnaires were sent to the persons who had not replied by October 1, and four were returned.

The background items decided upon rere pleced in the questionnaire which was sent to the persons who were selected as the subjects of this study. These items were: age group, occupation, place of residence, political party affiliation or preference, relfgious affiliation or preference, marital status and nationality. The date derived from these questions are summarized by combined and by individual groups in Chapter III, 1. The detailed maltiple tables are to be found in the appendix (Tables XV-XVII).

Additional materials were obtained through the questionnaire by asking questions concerning the face-to-face activities of letter writers in support of the ideas expressed by them in their letters, and concerning their reasons for writing (Chapter III, 2 and 4 ).

Through the same device further information was obtained with reference to the reading habits of letter writers (See Chapter III, 3). Tables corering letter writer consumption of magazines, and fiction and non-fiction books are to be found in the appendix (Tables XVIII-XX).

The above information, it was assumed, would afford the basis for comparing witers in the different frequency-group classifications and for arriving at conclusions concerning possible significant differences in the patterns of opinion as indicated by the letters. The letters are discussed in Chapter III, 5 and 6. These are derired and summarized from issues of the Courier Journal, June 1, 1946 through May 31, 1947. Code initials are used in place of the names of writers since information was elicited from 
them with the assurance that they would be guaranteed anonymity in the study for which their returned questionnaires were to be used.

After some of the questionnaires had been returned it was decided that a better view of the problem might be projected if it could be determined whether the policies of acceptance, rejection and editing of letters of the Courier Journal differed significantly from those of other dailies with large circulations. The findings of this inrestigation are presented in Chapter II.

This thesis is in large measure exploratory; to the miters knowledge no comparable study has been undertaken. Very little is known as to the public influence of letters-to-the-editor colunms. Although it is not the intention of the writer to assess the "Point of View" column as a former and reenforcer of public opinion, it is his decided impression that the colum is read closely by large numbers of persons and that "frequent" writers with rery positively stated opinions on public questions acquire significantly large followings. This opinion is also volunteered by several persons in charge of such colums in dailies with whom we had commmication.

On examining the questionnaires returned by letter writers, the miter's initial impression was that the "point of View letters are usually written against something. Further, most of those questioned indicated that they receive conslderable correspondence thanking them for carrying on their crusades against organized labor, communism, or whatever the writer's principal topic may be. This led to the consideration of the letters-to-the-editor colum as a kind of "social safety valve." Materials having a bearing on this are taken up in Chapters III and IV.

It is the hope of the writer to contribute to the knowledge of a phase of contemporary journalism and public opinion formation through establishing the basis for an understanding of the persons who are most active in utilizing the "Point of View" column. 
This paper includes a description of the popalar mind as expressed publicly through "Point of $\nabla i e w, "$ and an analysis of some of the factors which may impel persons to contribute to letters-to-the-editor colums with relativeIy great frequency. It may be conjectured that the popularity of such writers Iies in the similarity of their opinions to those of a sizable popular follorIng.

The writer's conclusions, based on the materlals described in Chapters II and III, are presented in Chapter IV. Finally, some statements concerning a few of the limitations of this thesis and suggestions for further research in this general area are included. 
Chapter II

The Louisville Courier Journal "Point of Viev" Column 
Chapter II. The Louisvilie Courier Journal "Point of View" Calum

1. Statement of Policy concerning the Acceptance, Rejection and Fditing of Letters.

The intention of the second chapter is to examine the policy of the Courier Joumal, with respect to the acceptance, rejecting and editing of reader letters, and to compare the policies of twelve other major dailies with it in order to determine how, generally, the policy of the courier Journel might affect the latitude of the opinions expressed in her letter columns and the selection of the letters. This determination should more clearly define the nature of the group of writers with which this thesis is primarily concerned.

The responsibility for the moint of View letter colum is that of Mr. Barry Bullock, of the Courier Journal editorial staff, whose palicy it is to print all Ietters submitted with the exceptions of those that are rejected for the following reasons:

(1) The letter is too long.

(2) The letter indulges too mach in personalitits..

(3) The letter is illegible.

(4) The letter is mitten on both sides of the paper.

(5) The letter contains apparent inaccuracies of fact.

The writer is given the option of correcting his letter, with the above points before him, and re-submitting it. Letters that are not rejected are either printed immediately or held until there is a place for then.

Sometimes publication is delayed to give space to letters dealing with mare urgent public issues, such as an election. Occasionally it is believed to be necessary to put an end to an exchange of letters after it has become 
apparent that both parties have exhausted their stores of arguments and are now repeating themselves. Jsually this is accomplished, formally, by the insertion of an "editor's note" after the last of a series, with one or more of the above reasons for terminating the series stated therein.

The editorial staff member in charge of the "Point of View" colum edits letters for grammar and sentence construction errors, and, sometimes, to shorten them for publication, if they exceed the word limit. Here, it is stated, an effort is made to aid the writer to express his thoughts more clearly and effectively. Mr. Bullock states that all editing of letters is guided by the principle of retaining, within space limitations, the basic integrity of the writer's point of view and presentation.

A comparative examination of the Courier Journal "Point of View" columns and those of twelve other dailies, to be named subsequently, reveals that more letters are printed and more space is allotted in the courier Journal, per week, then in any of the others.

It is the opinion of the writer and of Mr. Bullock that "Point of View" is one of the most frequently read features in the Courier Journal. No attempt has been made in this paper to evaluate the effect of published reader letters upon Courier Journal readers, but such an investigation might very well yield highly interesting results. The role of "Point of Vien" as an opinion maker, in relation to editorial poliey, would be an interesting and possibly significant research problem in the study of the influence of the press and the Sociology of Public Opinion.

2. The Courier Journal Poliey and the Polieies of Trelve other Hajor pailies with respect to Reader Letters. 
To secure information on the policles of other dailies with reepect to letter columns, sixteen letters were dispatched. These letters were so directed as to obtain replies from newspapers with large eirculations from as many of the regions of the country as possible. Twelve replies were received. The procedure to be followed in discussing the topic will be that of excerpting important statements from the letters received from the twelve newspapers, and comparing these statements of practice with that of the Louisville Courier Journal.

(1) The Atlanta Constitution, Atlanta, Ga.

There are no restrictions with the exception of length-we try to limit letters whenever possible to 200 words-and, of course, those of libel or bad taste. The letters are edited as all other copy for grammar and punctuation. He receive appraximately three times as many letters as we can use.

(2) The San Francisco Dxaminer, San Francisco, Calif.

We use letters as fillers.

The editorial page of all the Hearst Newspapers is on articles order (sic.) from $\mathrm{Mr}$. Hearst's office. So locally we do not have full control of our space for letters.

We probably publish about half the letters received. Reasons for discarding letters are because they are abusive, of other correspondents, of the paper, of public men - that is, unreasonably abusive.

Because they are illiterate and would require too much editing to get in shape. All letters referring adversely to religions are barred.

Because they are illegible. Because they are erroneous in premises. Because they are unslgned.

(3) The Seattle Post-Intelligencer, Seattle, Wash.

Space limitations make it impossible for us to print more than about 10 per cent of the letters received - they rm around 500 a week.... 
The only criterion used in selecting letters for publication. (if no question of libel or good taste is involved) is their interest. All things being equal, the shorter the letter the better its chance of being used. On controversial questions we are careful to gire each side equal space, and we do not permit our editorial position to sway us in our judgment....

We do not publish attacks on individual rellgious institutions (although abstrect religious arguments are not barred) and we draw the line against any letter which, in our judgment, would excite racial prejudice.

As a general rule, 300 words is the limit of an Individual letter. We always reserve the right to reduce the length of letters but we never edit them in such:a way as to change or distort their meaning.

(4) The Detroit Free Press, Detroit, Mich.

Our space permits us to print either in whole or in part, approximately ten per cent of the letters submitted for publication.

We have no fixed policy on what letters may or may not be used. They are judged wholly on their general interest.

(5) The Birwingham Ners-Age Herald, Birmingham, Ala.

- - In the Age Herald or in the Hews, one out of 15 or 20 letters will not be used. Usually it is not because the writer has written in bad taste, and it would require too much editing to make his letter conform to decent standards. Sometimes we get a letter which would be used if we could read it, but must be discarded for that reascn.....

We never refuse to print a letter on a political subject if it is in good taste, regardless of whether it agrees with policy; that hardly needs saying.....

If we edit letters we do so in order to make them shorter, to clarify the writer's viewpoint, if we think too many readers might needlessly be confused as to the writer's opinions. We hold such editing to a minimum. 
(6) The Washington Post, Washington, D. C.

- Generally our space permits us to use approximately seven letters daily (the space allotted is constant). We receive anywhere from 20 to 100 or more letters a day, depending on the season and whether there are any burning is sues in the news. . . The only restrictions we place on them are those imposed by good taste and libel. We make it a point to select letters giving as many points of view as possible; and there is a conscientious effort to gire a say to those who disagree with our editorial policy - . - We attempt to choose those that are the most timely, best written and best informed. We of course do not use letters that are obviously misleading or incorrect in their facts, unless it is for purposes of explaining those facts....

We frequently edit lang letters dom to their essential points, taking care not to distort the arguments presented.

(7) The New York Herald Tribune, New York, N. Y.

of letters received, we publish, in round numbers, generally belon twenty per cent.

The reasons for not publishing letters are myriad. The first rule is that open letters, ones not addressed directly to the New York Herald Iribune, be discarded; others which are discarded are those which are carbon copies of a communfation sent around to a number of other publications as well, those which contain libelous or false statements of fact, those which are emotional outbursts contributing nothing to the subject under discussion, those which are out of date, uninteresting and generally insipid. It would be easier, perhaps, to give reasons for publishing a letter. We look for material which argues with our editorials, wich provokes a lively discussion, which contributes materially to the point at issue, which introduces new information, and which is pleasingly, courteously and clearly presented. Unfortunately, due to limitations of space, we sometimes have to turn down very good letters.

One edits a letter with any of sereral point 8 in mind. Sometimes it is merely a case of correcting grammar.. - Sometimes it is a case of taking out repetitious material, or parts which contribute nothing really to the point the letter makes. 
(8) The New York Times, New York, N. Y.

The Times receives from fifty to one hundred letters dafly . . . As a rule from four to five letters are published each day ....

Letters are chosen for publication because of timeliness and general interest. Abusive letters, or those containing personal attacks on national figures are rejected....

Iditing is done where space considerations prevent publication of lengthy communications. Naturally the main argument of the writer is preserved, and no change is made of the language, when cuts are necessary.

(9) The Cincinnati Enquirer, Cincinnati, Ohio.

We publish Prom 60 to 70 Reader's Views a month and reject generally some 100 a month. ... We reject chiefly those letters that are too long and camnot be trimmed to 200 words or less. Also we reject obscene or anonymous letters, and don't encourage letters on such provocative subjects as Palestine, for there would be no and to such discussions. . . Generally we permit readers to roice views even if contrary to editorial policy.

(10) The Christian Science Monitor, Boston, Mass.

It receives letters from its readers in all parts of the world. Present space conditions permit the publication of only about ten per cent of the letters received.

Other than for space, our general reasons for not publishing letters are; libelous remarks; false statements of fact which are apt to mislead our readers; and purely crank letters with no constructive anglo....

We endeavor to give an equal proportion of space to both sides. We welcome expressions from readers in sincere disagreement with this paper's own views.

We try to do the cutting in such a way that it will not mar the reader's meaning or intent. We correct errors in grammar and spelling and delete abusire language. 
(11) The Chicago Tribune, Chicago, IIl.

The principal rule in selecting those we pubIish is that they should interest us. This arises from our concelted idea that if they should interest us they may conceirably interest our readers also.

Our mail averages 60 or more letters a day and we can print only five to seven. . . We try to give every shade of opinion its roice. . . . It is actually difficult to find letters opposed to our edit orial policies on some questions. . .

The only class of letters that I can think of that we would be likely to reject are those written by Communists, anti-vivisectionists and people who wish to argue sectarian religious questions, the latter because the ineritable replies would make us the innocent bystanders in some unchristian branls in print. . . O On other matters our critics can be as intemperate as they please, so long as they are not Ifbelous.

We have no compunction about editing copy, and in view of Iimitations of space have to edit it mercilessly. . . We are careful not to distort what the writer has to say.

(12) The St. Louis Post Dispatch, St. Louis, Mo.

I should say that we publish roughly a fourth of the letters received.

The main reasons why we reject letters are thet thej are incoherent or otherwise ill written, are from crack pots or based on misconceptions of fact, or continue discussion of subjects which hare already been worn out in the letter column. . .

We feel a special responsibility to print letters wich take is sue with our viewpoint, all other things being equal. We also feel a special obligation to print letters that make legitimate criticisms of our advertisers. Our policies for the editing of the letters we are to use are simply those of good copyreading. - - Sometimes a letter is received which attempts to make a valid point but is written by a person with so little skill at writing that it is almost hopeless. . . The feeling here is that we have a special responsibility towards letters such as these.

It seems, from the information above, that, with the exception of the Birmingham News-Age Herald, the percentages of those letters received published range from 5 per cent to about 50 per cent, with the majority printing between 
10 and 25 per cent. All the nerspapers polled, with the exception of the San Francisco Examiner wich uses letters as fillers, derote apace to reader letters regularly.

An examination of the policies of these dailies, with respect to acceptance and rejection, reveals that the policy of the Courier Journal seems rather less selective. Here, of course, space allottment plays a major part. A perusal of the Coarier Journal "Point of Vien" colums prores that letters are printed on quite a wide range of subjects, from those of serious public interest to those concemed ifth matters of libtle public or current interest, such as a witer's strictures on doge, with Biblical references, or plous reflections on Lother's Day.

The general requirement of good taste is stated by all those returning answers to the witers letter. It a minimm this would exclude libalous material. The exercise of judgment upon whether or not letters are in good taste, though not libelous, Iikely would depend upon the personal taste of the editor in charge of the colum, and the overmall policy of the paper. The statement of the Chicago Iribume, as contrested nith that of the St. Ionis Post Dispatch or the Ionisville Courier Journal, for example, is a case in point here. Commonists and anti-rivisectionists are in "bad taste," according to the Chieago Iribane.

It seems that after a letter is accepted for publication, editing practices vary little from newspaper to newopaper, and faller those of "good copyreading."

Lost replies stress, in conforwity ith the practices of good copyreading, that cuts, aither in view of space limitations or needless repetition on the part of the letter witer, are made vith care to preserve the integrity of the viewpoint and presentation of the writer. 
To sumarize, it is the conclusion of the writer of this essay that the Courfer Journal publishes letters on a greater number of topies and from a more representative group of those who write to newspapers than the other datlies surreged. A possible exception here is the Birmingham Nerre-Age Herald. The Courier Joarnal seems to allot more space to letters than the other dailies queried.

Policies, With respect to acceptance and rejection, are less restrictive in the Courier Journal "Point of View" colvms than in similar colwans sponsored by ont of the twelve dailles from which replies were secured.

Bditing policies do not seem to differ sigaticantly from newspaper to newspaper, though cutting would seem to be more drastic and frequent in the instances of newspapers whose space is more limited.

Finally, since there seems to be a close correspondence in the Courier Journal between the frequency with which individuals submit letters and the frequency of their publication, the table (See Appendix, Table XIV) sumarizing the number of letters witten orer a jear's time may indicate, roughly, both of these factors. Studies of many other dailies, using the approsech employed in this thesis (direct recourse to the letters-to-tho-editors columas), would not necessarily be studies of those who write most often but simply of those letter writ ers who are published most frequently. There might be little correspondence between publication frequencies and the frequencies with which letters were submitted by particular writers.

The forty-four whiters who are the major concern of this thesis, the writer concludes, probably submit letters for publication at roughly the same rates at which their letters are published. 
Chapter III

The Louisville Courier Journal "Point of View"

Letter Writer 
Chapter III. The Louisville Courier Journal "Point of View" Letter Writer.

\section{Personal Data (in tables) and Summarizations}

\section{A. The ages of letter writers}

The mean age of the forty-four letter miters is 59; the median age, 59; and the modal age-group, 65-69. Differences between Groups I, II, and III are not significant.

It is interesting, however, that the ages of the forty-four are on the whole rather advanced. The joungest persons returning questionnaires were in the 35-39 age-group, and there were but two of these. The conclusion is that the most frequent letter writers are in the upper age-groups.

\section{B. The occupations of letter writers}

The forty-four letter writers are predominantly members of the professional, business and white-collar classes (approximately 82 per cent). Writers were classified, roughly, as professional, business, white-collar, urban manual, farmer, and retired.

Group I had the lowest ratio of professional and business personnel and the highest ratio of "white-collar" personnel. Groups II and III each nearly doubles Group I's professional and business personnel and fall off to one-fifth the number of white collar personnel in Group I.

In the combined groups, the number of persons in occupational categories other than the first three is negligible, totaling eight, which is only one more than the number classified as "white collar." 
Combining the three groups we get the following distribution:

Table I. The Occupational Group Categories of Letter Writ ers

$\begin{array}{lr}\text { Professional } & 15 \\ \text { Business } & 14 \\ \text { White Collar } & 7 \\ \text { Orban Kanual } & 2 \\ \text { Parmer } & 3 \\ \text { Retired } & 3\end{array}$

c. Ietter Iriters and church affiliation or preference

Taking the combined groups we get the folloring picture of the distribution of church affiliations or preferences:

Table II. The Denominational Affiliations or Freferences of Letter Writers

\begin{tabular}{lcc} 
denomination & number & per cent \\
\cline { 2 - 3 } Baptist & 11 & 25 \\
None & 10 & 23 \\
Disciples & 5 & 11 \\
Methodist & 4 & 9 \\
Episcopal & 4 & 9 \\
Presbyterian & 4 & 9 \\
Catholic & 3 & 7 \\
Congregational & 1 & 2 \\
United Brethren & 1 & 2
\end{tabular}

Group I has a decidedly large proportion of its members in the WFundamentalist" demominations (Methodist, Baptist, Disciples, Catholic), 76 per cent, as compared with Groups II and III which have 67 por cent and 31 per cent, respectively. Group III has the largest percentage of those who answered "none" on the questionnaire.

Although the difference between Group I ("most frequent" writers) and Group II ("frequent" miters), with respect to the writ er's inference concerning doctrinal traditionalism, is insignificant, the marked difference between Groups I and II, and Group III ("moderate" writers) indicates a strong strain towards conservative theology on the part of the more frequent letter writers. Aside from the two persans who profess to no religious affiliation or preference 
in Group I, none of the persons associate themselves with divergent" sects or denominations. Distribution among the rarious denominations, indicated for the combined groups, is mach wider in Groups II and III than in Group I. An interesting phenomenon here is the comparatively small number of Catholics in the combined groups, given the preponderance of Lovisvillians among the letter mit ers. Louisville's Catholic minority seems to be very mach under-represented.

D. Letter writers and political party affiliation or preference

Group I includes a greater proportion of Republicans than Groups II and III, though the difference between Groups I and II is not marked enough to be significant. There is, however, a distinct walling off in Group III, in which only 13 per cent record themselves as Republicans, as compared to 38 per cent and 33 per cent for Groups I and II respectively. In the South, particularly, political party affiliation or preference, in itself, is not necessarily an accurate index to the radical-liberal-conservative orientation of individuals. The letter content of these persons, rith a few exceptions, indicates a decidedly conservative political and social orientation, even when they call themselves "Democrats" or "Independents." Judging from their letters, the letter writers who profess to be "Independent" ardinarily are conservatively oriented. Their reluctance to identify themselves with one or the other major party is not an indication of "independent" thinking about economic, political and social issues.

In general, the writ er would observe that departure from a conservative political Ideology is much more pronounced in the contributions of writers participating at low frequency rates than in the contributions of those perscns in Groups I and II. This is a hypothetical observation only, and a direct textual validation of the point would take the writer outside the scope of this paper. 
E. The formal education of letter writers

According to the writer's data on this point the combined groups of letter writers arrange themselves as follows: mean, approximately 13 years; median, 13 years; modes, 12 and 16 years.

Group II has the highest number of college graduates (8); Group III, the next highest number (4); and, Group I, the fewest (3).

The averages of Group I and of Group III (years of formal education) are approximately the same. However, if one letter writer, who has had no formal education (in Group II) is left out, the average of Group II is markedly higher than that of Group I.

The use of the mode and the median, with respect to formal education, places the groups in the following order: Group II, Group III and Group I.

The application of the above measures to the three groups and the comparison of the results show very few significant differences. The preponderance of professional persons in Group II gives it an advantage in formal education, though by no means a decisive one.

Most of the writers who have had college educations are professionals, with lawyers predominating. The teachers listed are elementary school teachers. With the exception of one writer in Group III, who has had social welfare training, few writers give substantial evidence of having had specific informational background to write on the subjects they discuss with reasonable authority. This point is further substantiated by an examination of the usual reading materials consumed by "Point of View" writers, and is especially strengthened by examination of the content of the letters they write. The "very frequent" or "chronic" letter writers are particularly weak, jucing from their showings on the above points. 
F. The marital statuses of letter writers.

An examination of the marital statuses of the forty-four letter writers shows that the persons in Group I seem to conform very closely to traditional norns. The percentage of those married is significantly higher than the percentages for Groups II and III, and there are no "divorced," "dirorced and remarried," or "separated" persons in Group I, Jhereas these comprise 33 per cent and 38 per cent of the persons in Groups II and III, respectively.

The tabulation for the combined groups is as follows:

Table III. The Marital Statuses of Letter Frit ers

$\begin{array}{lr}\text { Married } & 24 \\ \text { Single } & 7 \\ \text { Divorced } & 3 \\ \text { Divorced and Remarried } & 7 \\ \text { Separated } & 1 \\ \text { Midored } & 2\end{array}$

G. The nationalities of letter uriters

The answers to the question of nationality were, with few exceptions, "American." Sometimes there was a qualifying prefix, as to descent. Occasionally such expressions as "100\%," "Ihank God," and "First, last, and forever" (sic.) were affixed. One writer answered simply - "gentile." The writer of this essay assumes that he meant "100\%" American. Most writers volunteered the information that they were of Scotch-Irish or of English descent.

Only a few persons diterged from the above: one, a woman who answered "negro-anerican," and man who answered "Swiss."

An interesting feature of several answers was the extension of the reply to the backs of a page or two of the questionnaire, on which a precis of the writer's ancestral background was sketched. This was done by several of the persons in the older age-groups and was an interesting example of the "pride of family" which is thought to be characteristic of persons in some sections of Kentucks. 
H. The place and length of residence of letter writers

Approximately 92 per cent of the miters in Group I ("most frequent" or "chronie" letter wit ers) are residents of Kentucky, and approximately 67 per cent are residents of Louisville. Writers in Groups II ("frequent" letter writers) and III ("moderate" letter writers) are more frequently out-of-state residents, or residents in the state, but outside Louisville.

The differences in average length of residence (in city or tomn) in Groups I, II, and III are not significant, particularly if one considers that many of the estimates in the returned questionnaires are admitted to be appraximations only.

Generally the mean length of residence in the town or city from which "Point of View" writers come was approximately 18 years and 8 months. The median for length of residence is 13 years. These sereral measures Indicate that, on the whole, the group has considerable stability of residence.

\section{The Personal Activity of Letter Writers With Respect to Media

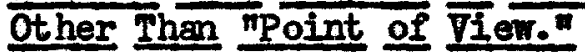

A. Personal contact and activity in behalf of ideas exoressed in the IPoint of Viewn section.

The data under "A" are derived from the answers to questions $1,2,3$, and 4 of the questionnaire. I shall take up the questions and the writers' enswers to them in order.

Question 1. Do you debate the issues with which your letters are concerned with others who have similar points of view but who do not write?

Twenty-six (59 per cent) of the writers gave an affirmative answer to this question. The breakdown into Groups I, II, and III reveals the following: 
Table IV. Percentages of Letter Writers Who Discuss Letters With Those Who Do Not Write

\begin{tabular}{|c|c|c|c|c|c|c|c|c|}
\hline Answer & Com & Groups & Gro & & Gro & II & Gre & III \\
\hline & no. & per cent & no. & per cent, & no. & per cent & no. & per cent \\
\hline Yes & 26 & 59 & 9 & 69 & 6 & 40 & 11 & 69 \\
\hline No & 18 & 41 & 4 & 31 & 9 & 60 & 5 & 31 \\
\hline
\end{tabular}

Question 2. Do you discuss the idess, of which you write, wh thers who also write?

Table V. Percentages of Letter Writers Who Discuss Letters With Other Writers

\begin{tabular}{|c|c|c|c|c|c|c|c|c|}
\hline Answer & $\operatorname{Com}$ & droups & Gro & & Gre & II & Gro & III \\
\hline & no. & per cent & no. & per cent & no. & per cent & no. & per cent \\
\hline$\overline{Y e s}$ & 17 & 39 & 3 & 23 & 5 & 33 & 9 & 56 \\
\hline Ho & 27 & 61 & 10 & 77 & 10 & 67 & 7 & $4 h$ \\
\hline
\end{tabular}

Question 3. Do you encourage your friends to write?

Table VI. Percentages of Letter Friters Who Fncourage Friends to Write

\begin{tabular}{|c|c|c|c|c|c|c|c|c|}
\hline Ansmer & Com & d Groups & Gro & & Gro & II & Gron & III \\
\hline & no. & per cent & no. & per cent & no. & per cent & no. & per cent \\
\hline Yes & 18 & 41 & 4 & 31 & 5 & 33 & 9 & 56 \\
\hline So & 26 & 59 & 9 & 69 & 10 & 67 & 7 & 44 \\
\hline
\end{tabular}

Question 4. Were jou encouraged by someone else to write to the Courier Journal "Point of View" column?

Table VII. Percentages of Letter Writers Who Were Encouraged to Write By Others

\begin{tabular}{|c|c|c|c|c|c|c|c|c|}
\hline Answer & Com & at Groups & Gro & & Gro & II & Gro & III \\
\hline & no. & per cent & no. & per cent & no. & per cent & no. & per cent \\
\hline Yes & 8 & 19 & 1 & 8 & 4 & 27 & 3 & 19 \\
\hline No & 36 & 81 & 12 & 92 & 11 & 73 & 13 & 81 \\
\hline
\end{tabular}

The answers to the four preceding questions show that letter writers are rather active with respect to supporting their ideas, aside from letter writing. Howerer, more negative than affirmative answers were given to questions 1,2 , and 3 which indicate activity on the part of the letter writer himself.

The replies to question 4 show that the overwhelming majority of the letter writers began to write on their onn initiatives, though approximately 47 per cent urge their friends to write. 
By groups-Group II ("frequent" writers) would seem to be least participant, with Group I ("most frequent" witers) occupying the middle place, and Group III ("moderate" writers) most participant. The difference between Groups I and II is slight, howrever.

Ninety-two per cent of the writ ers in Group I were not encouraged to write, a significantly higher proportion than the combined groups percentage.

B. Publication in media other than the Courier Journal "Point of Vien" colum

Thirty-seven letter writers have been published in "media other than the Courler Journal 'Point of View' colum." Iwenty-three have published letters in other newspapers and sixteen heve published either in general periodicals, pamphlets, and books.

Question 5. Have you published anything in places other than the "Point of View colum? If so, where?

Table VIII. Percentages of Letter Writers Who Have Published in Media Other Than the "Point of View" Colum

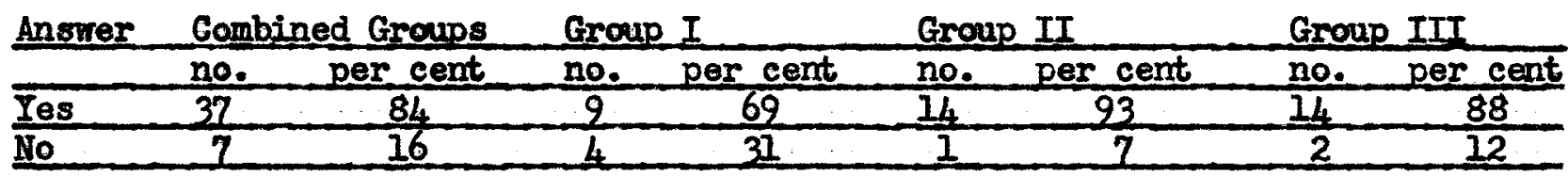

Table IX. Other Publications of Letter Writers

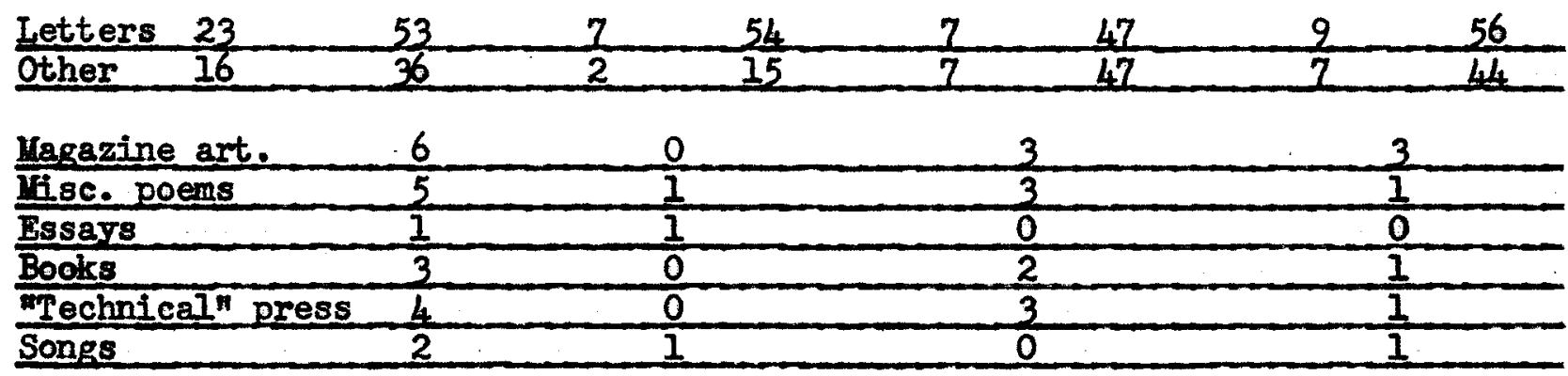


The foregoing summary table shows that a majority of the letter writers also have letters published in other newspapers. Their record of participation here is more impressive than the record of their "person-to-person" activity. A sizable number ( 36 per cent) also utilize aremues other than letter colums, though evidence here is that such utilization is not, on the whole, concermed nith the ideas expressed by them in "Point of View."

The breakdown by groups shows that Groups II and III rely much less than Group I on letters-to-the-editor for their public expression. Fewer persons in Group I have been published out side the daily press, and the persons in Group I, of course, participate in "Point of View much more frequently than those in Groups II and III.

3. The Reading Habits of moint of View Letter Mriters

A. Newspapers

Question 6. Which newspapers other than the Courier Journal or the Lovisville Times do you subseribe to or read regularly?

Twenty-one of the letter writers read or regularly subscribed to no daily newspapers other than the Courier Journal-Times. Less than half (6) of the persons in Group I subscribed to or read regularly dailies other than the Courier Journal-Times. Those who did read other dailies averaged approximateIy three additional newspapers. The most popular out side daily was the Chicago Iribune, with the Cincinnati Post and the New York Herald Pribune as second choices.

Sixty per cent (9) of the writers in Group II subscribed to or read regularly dailies other than the Louisville papers. Those who did, averaged two additional papers. The New York Times was the most popular newspaper with this group. 
Fifty per cent (8) of the writers in Group III read other dailies. They averaged $2 \frac{1}{2}$ newspapers, exclusive of the Louisville papers. The most popular daily was the Chicago Tribune, which was read by four. Second most popular was the New York Times, read by three persons.

The striking thing about the forty-four letter writers is the overwhelmingly conservative character of their daily press readings. Only four persons professed to read dailies of liberal political reputations, aside from the Courier Journal-Times, such as P.M. (2), the Chicago Sun (3), and the St. Louis Post Dispatch (1). These are not as many as have access, usually, to either the New York Times (6) or the Chicago Iribune (8). Three of the writers who do read "dajlies of liberal political reputations" are in Group III.

\section{B. Magazines}

Question 7. Which magazines do you subscribe to or read regularly?

The average number of magazines read was three. On the point of average numbers read, the differences between Groups I, II, and III were negligible.

Over fifty per cent of the letter writers (25) either subscribe to or read regularly, Reader's Digest. Next in popularity is the Saturday Evening Post, listed under question 7 by 25 per cent (II) of the letter writers. Hanking behind the se are Time, Life, and Colliers in the order given.

Publications, reputedly for the more serious-minded reader, such as the New Republic, The Nation, Harpers, and the Atlantic Monthly which are read by few are also listed by few letter writers. There are only three persons in the group of forty-four who read any one of these regularly, and one of these 
accounts for one of the two New Hepublics read and the only copy of the Nation listed. No persons in Group I read any one of these publications regularly and only one person in Group II does so, the remainder being accounted for by two persons in Group III.

One is impressed by the number of persons who read "digests" of one sort or another. They are listed in thirty-one instances and account for about 25 per cent of the total magazine readings of the forty-four letter writers.

Group III shows the broadest scope of magazine reading and more preference than the other groups for magazines that are not in the upper ranks of the newsstand best-seller group.

In conclusion it may be said that the reading of letter writers in this sphere is rather impressively favorable towards the popular conservative periodicals, with approximately 46 per cent of the magazines read regularly being of the Reader's Digest, Saturdar Evening Post, Colliers, Iife, Time group. Only 4 per cent of the magazines were of the New Republie, Nation, Harpers, and Atlantic Monthly group.

In answer to question 8 - which of the above magazines or newspapers do you enjoy most, or most approve? - twelve writers indicated Reader's Digest and eleven preferred the Courier Journal. Other preferences were widely scattered, the third place favorites having only three votes each.

\section{Fiction (books)}

Question 9. Which do you consider the best works of fiction (list at least ten, if possible) you have read during the past five years?

Twenty-nine professed to having read no fiction for this period of time. A few specified that they considered fiction a waste of time. The most concise answer was given by $\nabla$. Y. who wrote simply - Mever read the - - - " 
only seren persons listed more than two books of fiction. Of these, the readings of two were novels of a religious tenor, principally; two read books concerned with social and racial questions (in Group III); the selections of two must be classified as "miscellaneous" (Group II); and another, in Group I, reads mostly fiction of the Book-of-the-Month Club historical tJpe.

Three persons list the names of favorite authors but list no titles. One of these inclines towards historical-adventure fiction of the Alexander Dumas-Margaret Mitchell genre; another lists writers of sentimental fiction, such as Temple Bailey and Bess Aldrich; the third reads serious contemporary novels and lists E. Hemingway, E. Caldwell, and others.

Four persons read the "classics" or the "classics and poetry." They list no authors and no titles.

From the above it will be seen that a substantial majority of letter writers read no fiction and that only three persons read fiction concerned with social questions, which constitute the usual subject matter of their letters. Two of these are in Group III, and these are the same writers who subscribe to liberal newspapers and magazines. One of the above three is in Group II.

Group II has the fewest "none at all" answers (8) to question 9. Groups I and III have 9 and 12 such answers, respectively.

\section{Non-Fiction (books)}

Question 10. What are the best non-fictional works you have read during the same period (five years). Iist 10, if possible.

Fifteen, or about 33 per cent of the letter writers read no nonfiction. All but one of these also had read no fiction. The highest proportion of those reading no non-fiction, and reading neither non-fiction nor fiction is in Group I (6 and 6); the lowest in Group III (5 and 4). 
Five letter writers in Group I listed more than two non-fiction books; six, in Group II; and, three, in Group III.

The favorite reading of "Point of View" writers seems to be biography and history. A majority of the personal accounts consisted of books by World War II journalists.

In this category their readings on aspects of the problems about which they write are negligible. Only fire persons, of twenty-nine, have done such directed reading. Two of these are in Group III and are the same persons whose reading has been commented upon in the middle of page 25 of this thesis (Z. O. and Z. I.). Z. O. and Z. I. have the most consistently above average records on the points of formal education, and newspaper, magazine, non-fiction and fiction readings. Their letters indicate a comparatively higher degree of sophistication and informational superiority to those of other letter writers, though their rates of participation place them in the "moderate" group.

It would be the general conclusion of the writer, for Section 3, that letter writers in all three groups depend overwhelmingly on popular newspapers and magazines for their information. The materials to which they have access are, for the most part, slanted towards the political and social right. With a few exceptions, then, the reading of pertinent books and recourse to expert opinion are negligible factors in the informational backgrounds of "Point of View" writers. This is particularly true of Group I and to a lesser degree of Groups III and II. Group II has the most impressive record here.

\section{Why Do Letter Writers Write?}

Question 11. With regard to the letters you write, how effective do you believe them to be? Is it your opinion that the good done justifies the time and energy expended in their writing? 
Table X. Letter Writers Opinions As to Whether Letters Are Effective Or Not

\begin{tabular}{lcccc}
\hline & Ies & No & Non-commital & Other \\
\hline Group I & 5 & 3 & 3 & 2 \\
\hline Group II & 9 & 1 & 5 & 0 \\
\hline Group III & 10 & 1 & 5 & 0 \\
\hline AII & 24 & 5 & 13 & 2 \\
\hline
\end{tabular}

By the above it is shown that a majority of the letter writers are convinced that their activity is helpful to their causes and justifies the time they give to it. Those who answered the question with a categorical "no" were very mach in the minority. The two persons whose answers were classified "other" admitted that their activities were motivated by the "free advertising" they received.

The breakdown into groups, curiously encugh, indicates that the persons in Group I ("most frequent" or "chronic" writers) are more pessimistic as to the value of their letter writing, in terms of the wording of the question, than those in the other groups.

Highly significant was the comment, in a number of cases, that the writer's chief satisfaction was the opportunity to "blow off steam." The remainder of Section 6 will concern itself with the testimony of letter writers on this matter. Remarks which do not seem directly to support the thesis of the "Point of View" calumn as a social "safety valve" but which imply that the writer is getting something "off his chest" are included.

It is the belief of the writer of this essay that the high incidence of "crusades" against some imagined social evil or other constitutes supporting evidence for the above thesis. A perusal of the following excerpts and the content and emotional bias indicated in the letters summarized in Section 6 of Chapter III give considerable weight to the social "safety valve" contention. 
An additional series of excerpts will give information cancerming the letter writer's estimate of the success of his activity, aside from the admissions that, in their opinion, the letters are either effective or not effective.

Question 11 was purposely worded in a very general fashion to encourage writers to write extensively about their feelings concerning their activities. A note asked them to use the backs of the sheets of the questionnaire, if more space were desired.

Excerpts (series I)

V. Y. - I get mail thanking me and three letters threatening my life were received from out-of-town telling me to 'lay off' fighting refugees entry into this country. The writers suggested that I let all of the Jews come to this country then certain parties will know where they are all located when the time comes. I ignore the threats and intend to carry on the fight.... "Kikes" not Jews hate my guts because of my fight against giving this country to the Jews.

S. G. - I often feel that a letter in a P. V. is about as effective, relative to great and deep issues, as throwing a powder puff against the Rocky Mountains. - . The energy expended is never considered. It is a joy to express oneself against erroneous and hurtful ideas and propositions if there is a deep moral conviction. . . Now reading 'Communism in Action' in correlation with other material on Communism (hate communism). Have no opinion on anything else.

T. Y. - The se letters may or may not create public opinion but they are counted as part of public opinion and I feel that anything that $I$ can do to counteract the anti-american propaganda that has been so prevalent is my patriotic duty and is worth the money, time and effort in doing it. (This writer mimeographys copies of his letters and sends them to dailies throughout the country.

T. D. - I do not write with any desire to 'change the world' as a reformer with cosmic-significance convictions. My writing is the product of a 'tiny tempest in a teapot,' a sort of brain storm. My compulsion neurosis, or sumpin', must express itself. And I do not feel just right until the temporary complex is relieved and the tension released.

G. Y. - My writing is impulsive on issue at hand. 
Y. V. - The Courier Journal-Times need competition in Louisville, and much less tosdying to bankrupt European and Asiatic philosophies.

U. N. 2 - Many people have written me that I should continue to mite and help defeat Communism, but too few are interested.

V. Y. - If I had not received many letters from people all over the state and occasionally from other states - I would not have kept on writing. . . I Ieel so deeply what I write. I suppose that is what gives my letters a real punch. . . If one man like Hitler, working with the devil could accomplish what Hitler did - why could not one insignificant seeming person like myself accomplish much by working on the side of the right. This has ennobled me to speak boldly against wrongs perpetuated by our gorernment and its leaders. . . . Roosevelt and his wife have made more drunkards than anybody else.

V. Z. N. - reports that letter writing is ia help in convalescence,' a form of 'occupational therapy.' She gives a relatively complete life history on her questionnaire in answer to this question, and enclosed a four page letter continuing this history to the time of mailing. "Many people tell me that they read my letters and like them.' (underlining, V. Z. N.'s)

Z. I. - Judging from the letters I receive- - -some of them threatening but anonymous, I believe that my letters to the Point of View are effective.

If my letters to the 'Point of View' arouse even one person to the point of examining the logic of his belief in 'white supremacy' and 'negro inferiority' I shall feel that the time and energy expended is worthwile.

H. I. - I hear from others all orer the country.

My object is to try to tell these people who are neither wet nor dry the truth about the misrepresentations of the professional prohibitionists and their allies the preachers. . . who are afraid not to preach prohibition propaganda disguised as temperance education.

Z. X. - Most of my letters are in contradiction to the narrow views of the two papers and just want to 'hit back' however small the result. 
X. I. - Probably do but very little, if any good, but do allow me to 'blow off a little steam,' when as so often happens I get a little thot under the collar."

Q. S. - I feel my time writing is well spent. Get ideas out of my system, and is my recreation.

Excerpts (Series 2)

I. W. - Judging from the favorable as well as unfavorable response I get from all parts of the U. S., I am very well pleased with my weak efforts. (Mentions letters from J. Edgar Hoover, congressmen, judges and F. D. Roosevelt (?).)

0. I. - I do believe the good accomplished justifies the time involved. . . I Inow from the amount of correspondence received, some of which is not in agreement.

X. M. - I cannot say how effective they may be but I do know from my friends I have a large circulation.'

V. N. - Judging by the many letters I have received from both men and women I should say mine are effective. Ninety per cent agree with my opinions.

H. V. - I think I have done quite a little for my cause. Friends and acquaintances in various sections are my witnesses.

Q. Q. - I have received many letters from people who agreed or disagreed with me. . . I never write an article unless it will serve a need or call to people's attention a vital fact that I think many of them are missing.

Z. S. - I receive many letters of approval, especially from elderly people.

G. U. - Some of the writers of letters agree with me and some don't. It shows, however, that these letters are read with interest.

2. 0. - I dereloped the habit when an active Socialist because it was the only form of propaganda I could do single-handed and we had little of an organization; the news colums of the newspapers at any rate paid little or no attention to Socialist meetings. Since then I have been advised by men in the advertising business that the letters to paper are read more than any other feature except, of course, the sports and the comics. 
31.

S. 2. - Judging from many letters received from those who read my letters I believe they have considerable influence upon public thought. 
5. Summarization and breakdown by groups of letters by fields and by most popular topies.

The total number of letters witten by the forty-four correspondents, from June 1, 1946 through Nay 31, 1947, was 384. Of these, 212 or 51 per cent were written by Group I; 122 or 35 per cent by Group II; and 50 or 14 per cent by Group III. Average writers in the three groups wrote 16.7, 8.1, and 3.1 letters respectively.

By field, the major interest of all the groups was "National Affairs," with 34 per cent of the letters thus classified. The other percentages, with respect to fields, may be listed as follows: General, 26 per cent; International and Foreign Affairs, 17 per cent; State Affairs, 11 per cent; and, Local Affairs, 11 per cent.

The interests of the three groups, separately, may be given as follows: Table XI. The Interests of Letter Writers According to Fields Letter Percentages

\begin{tabular}{|c|c|c|c|c|}
\hline Fleld & Combined & Group I & Group II & Group III \\
\hline Int II. and Foreign & 17.4 & 15.2 & 22.0 & 12.2 \\
\hline National & 34.3 & 36.0 & 27.6 & 46.9 \\
\hline State & 11.2 & 10.7 & 12.2 & 8.2 \\
\hline Local & $\overline{11.2}$ & 9.4 & 13.0 & 74.3 \\
\hline General & 26.0 & 28.1 & 25.2 & 18.4 \\
\hline
\end{tabular}

From the above it will be seen that Group I has a slightly larger concentration of letters under "General" and "National," than the average, with lower than average concentrations under "Local," and "International and Foreign Affairs."

Group II indicates a marked preference for discussion of topics under "International and Foreign Affairs," a greater than average interest in "Local" and "State" Affairs, and a less then average interest in "National Affairs." 
Group III shows a decided preference for topics under "Nationel Affairs," a greater than average interest in Local Affairs, and decided drops from average in the remaining three categories.

In turning to a consideration of the concentration of writers upon topics, the writer is impressed by the fact that 11 ( 25 per cent) of the forty-four writers wrote 50 per cent, or more, of their letters on single favorite topics; approximately 19 ( 43 per cent), 33 per cent or more; and 28 writers ( 77 per cent, approximately), 25 per cent, or more. The foregoing includes anly those who wrote at least two letters on a favorite topic. The breakdown by groups is as fallows:

Table XII. Individual Writer Concentrations on Favorite Topics

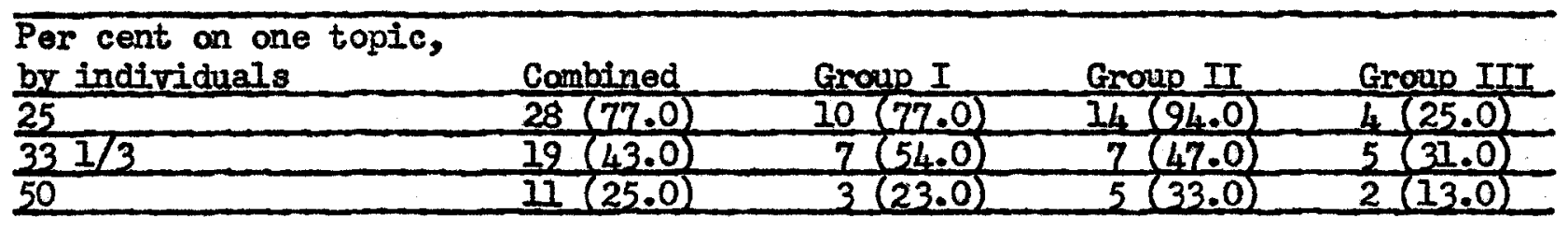

By the above it will be seen that letter writers in Groups I (" most frequent" writers) and Group II ("frequent" writers) are much more inclined to concentrate upon farorite topics than are those in Group III ("moderate" writers), and that Group II concentrates more determinedly than Group I, in two out of three measures.

A look at the five most popular topics (letters on "labor" in all fields, and letters on the Sovlet Union and Communism are combined here) reveals that 128.5 letters or 33.46 per cent of all letters were written on these topics. 
Table XIII. Percentages of Letters Written on the Parorite Topics of the Writers

\begin{tabular}{lccccc}
\hline Topic & Combined & Group I & Group II & Group III \\
\hline Organized Labor & $32.0(8.3)$ & $19(8.9)$ & $8.0(6.6)$ & $5.0(10.0)$ \\
\hline The New Deal & $25.5(6.7)$ & 21 & $(9.9)$ & $1.5(1.2)$ & 3 \\
\hline OPA-Cost of Living & $24.5(6.4)$ & 14 & $(6.5)$ & $7.0(5.7)$ & $3.5(7.0)$ \\
\hline Drinking, Gambling & $24.0(6.2)$ & $13(6.7)$ & $7.0(5.7)$ & $4.0(8.0)$ \\
\hline Soviet Union \& C. & $23.5(6.0)$ & $11(5.0)$ & $9.5(7.8)$ & 1 & $(2.0)$ \\
\hline
\end{tabular}

The percentages, in the parentheses above, are based upon the total numbers of letters written by the three groups.

The percentage figures he re are used to show the relative popularity of these subjects in terms of letters written by the groups, individually and combined. They are based in the first instance, on the total numbers of letters mitten by each group separately, and in the second instance, upon the combination of the total letters written by each group and the total numbers of letters written on the five designated topics.

Analysis of the immediately preceding table shows that "Labor" was most popular with Groups I ("most frequent" writers) and III ("moderate" writers), both having significantly above average percentages; "Soviet Union and Commonism" was most popular with Group II ("frequent" writers), Groups I and III showing definitely below average percentages; the "New Deal" was high with Group I and low with Groups II and III; showings on nOPA-Cost of Living" do not vary much from one group to another; and, "Gambling and Drinking" is below average in all groups but Group III, where it is decidedly above average. However, in the cases of all topics, with a slight departure in the instance of "New Deal," gross numerical comparisons of letters written find Groups I, II, and III in the order given, fran high to low.

Something has been shown of the distribution of letters in terms of individual concentration upon single topics; distribution of letters according 
to field by "combined groups," and by Groups I, II, and III; simple numerical distribution by topic; and, distribution of letters on the five most popular topics by combined groups and by Groups I, II, and III.

In preparation for Section 6 it is interesting to note the following concentrations:

(1) On the topic "Organized Labor," four letter writers wrote 17 letters between them, which is 53 per cent of all letters written on this topic. The same writers wrote only 11 per cent of all the letters written on all topies.

(2) Two writers accounted for 13 or 52 per cent of the letters written on the "New Deal." They wrote only 17 per cent of all the letters written.

(3) Four writers produced 16 or 66 per cent of the letters on "Gambling and Drinking." Otherwise, they were persons with rather low rates of letter writing frequency, writing only 9 per cent of all letters. Two of the four above mentioned persons (in the questionnaire) admitted that this was the question of paramount interest to them and at least one makes a sort of profession of being a "wet" (See "H. Y."). 
6. Groups I and II and the Most Popular Letter Topics for the Period, June 1, 1946 - May 31, 1947 .

A. Soviet Russia and Communism.

The reactions of "point of View" writers may be described as decidedly "anti-Commistic." They have tendencies to identify "Communism" with whatever, to them, smscks of "radicalism." The especially popular identifications are the "New Deal" and "Organized Labor." They consist mainly of uncritical, badtempered assertions of identification, as the following expositions of views on the most popular topies will make clear.

The following materials are excerpts and summaries of letters, with an occasional remark calling attention to some apparently significant factors in the backgrounds of the writers.

It might be interesting to begin with a letter written by $\nabla$. Y. on "What Starts Communism," the only one stressing this aspect.

The promises of politicians and their failure to fulfill the se promises, workingmen finding it necessary to stop production because of inefficiency in governmental bureaus,... all this and the OPA too breed communism. Who fears communism most? The men who should be doing something about restoring democracy to this nation, are the clergy, the capitalists and the politicians.

V. Y.'s principal crusade is the anti-refugee one. (c.f., p. 35)

Z. S. writes the only letter which carries the isolationist argument in its most recognizable form. He asserts that we have helped the little nations exchange a Hitler for a Stalin; the United States needs a return to "sense, reason, and true Americanism." Internationalism is "done for" and the people are awakening to the fact.

I. W. deplores Franklin Roosevelt's recognition of Russia, which is called "communistic and godless." Roosevelt, he hints, is also responsible for World War II, and he foresees war with Russia as a "possibility." 
In a second letter I. W. calls for a firing of Communist Party members in "high position." "It is very evident Communism never had a chance in America until the New Deal came into power, bringing with it what the New Dealers call Liberalism, in other words Socialism, which is a step toward Commanism."

A third letter from I. W. makes the same points as the above two letters.

U. N. 2 mrites on WTallace and Commmism." He (U. N. 2) is ...

a pure-bred American in my small way, but, if I am not a bigger man than Henry Wallace, I am out of place on this earth. I think Henry Wallace and Elliott Roosevelt belong behind the iron curtain.

I wrote our representative in Washington, all during the war, that our great President, F. D. R., was being taken in by a cunning, satanic spirit from another world (Joe Stalin), and that when Cermany went down Communism would flood Europe and the rest of the world.

0. Y., whose letters reveal hin as a constant apologist for the Roman Catholic Church, finds that Bishop Oxnam's (Methodist) reluctance to fight the Cormmints is due to his extreme antagonism for the Mother Church," the church most feared by Moscow. With respect to Cammunist Party members he writes:

I believe it imperative to destroy them wherever they appear, whether it be under the protective wings of politicians, labor racketeers or even possibly churchmen.

I. V. estimates that there are about a half million commanists in our midst (Martin Ebon's estimate in World Communism, 75,000-90,000) and that they are, by definition, traitors. He asks that they be deported either to the U. S. S. R. or to mandated Pacific Ocean islands. "Let's get tough."

S. G. denies that Communists are citizens:

The primary tenet of their philosophy puts them on the out side of the lowest order of society recorded in history. To be a Communist one must foreswear his allegiance to country, God, and family. 
Under the Constitution the country has the right, and may we say duty to declare any individual, or group, outside the status of human rights who in his sane mind unalterably poses himself against all human rights. We do not allow free assembly of murderers, bank robbers, and dope peddlers. And the warped nuts in these categories are angels of mercy by the side of a cold, cunning communist under the spell of his fanatical oath.

O. Y., the Catholic apologist, makes no apologies for Franco and reports that:

Catholics do not hate Communists and Russia. They merely hate the evil inspired by its Codless rulers. We pray daily for Russia. . . The "totalitarian" states of Spain, Portugal and Argentina cannot, of course be mentioned in the same breath with Hitler, Germany, and Russia.

In another letter, 0 . Y. fears the consequences of a UNo-supervised free election in Spain which might result "In a repetition of the farce which placed in power the Communist-ridden Loyalist clique." He goes on to say that there is no greater menace than the USSR, and that Russia made World War II possible by her non-aggression pact with Hitler.

In still another letter 0 . Y. calls those who plead the cause of Republican Spain "dupes of Russia." He is replying here to a letter in "Point of View" by Scott Nearing.

Y. V. finds it difficult to conceive of Spain as a menace to world democracy. "Brutal Russia shedding pious tears over democracy is a laugh." Russia helped Franco by interfering in Spain. "If we really want to get rid of a dictator, there is Stalin."

X. A. sees Russia and Argentina as our enemies. He suggests that we break off relations and arm for World War III.

T. D., who doesn't seem quite disposed to declare war against mussia at the moment, deplores our aid to Greece and Turkey, which he calls an act 
"setting the stage for military entanglements." The Truman doctrine is a phase of American Imperialism, according to T. B. He considers that such aggressive activities are "a form of dodge from solving such grave domestic problems as the housing shortage," and that we are not really interested so much in saving democracy as in saving capitalism.

A somewhat contrasting point of view is posed by T. Y. who writes:

A lot of free food may help Greece a little, but what it really needs is an F. B. I. and a committee of Ungrecian Activities, plus the good old European lead-pipe rule. "Do unto others as they would do unto you."

In a second letter T. Y. finds that war with Russia is probable "because the oriental mind of Stalin sees slavery as the natural way of life, while American people abhor it." He believes, somehow, that it all goes back to "greed" which is his conclusion about all persons and groups he dislikes. He makes honorable exceptions of business men and good Republicans.

In a third letter T. I. reveals that Russia manifests the signs of decadence that presaged the fall of Rome - the rule by selfish little cliques. Our job is to "tell the Russians about the clique." Our moralist-philosopher has here turned historian.

T. Y. settles the question of atamic bomb control by insisting that we should have it, because we are peace-loving, god-fearing, respecters of the rights of others. Russia would only use same to extend her power.

V. I. 2 finds hope in the thought that Russia may go down before the small nations that she is trampling upon.

U. N. 2, the most frequent contributor on Russia, asks the questionwhy argue with Russia? Stalin and henchmen should have been tried at Nuernberg. The bomb dropped on Nagasaki should have been directed to Moscow. Communists are "the enemies of the human race." There are lot $s$ of then in the United States, including Henry A. Wallace. 
These themes recur in a number of U. N. 2's letters. A variation is the following remark in a letter for April 2, 1947 - "To reduce taxation, tame the Russian bearl"

G. G. writes that Russia must be given an ultimatu to "cooperate or fight." He is of the opinion that Russia intends to "rule the world," and that it would be more expedient for the United States to fight now, if Russia doesn't "cooperate."

X. X. hopes he is wrong, but hears from a "reliable correspondent" that Russia has three five-year plans' for World War III. He calls for a showdown now. 


\section{B. The New Deal}

"Point of View" writers in Groups I ("most frequent") and II ("frequent") are overwhelmingly antagonistic to the New Deal, as will be seen subsequently. Only one of fifteen letters to be briefed in this section can be described as sympathetic. The remaining five writers (writing fourteen letters between them) are roundly condemnatory of the New Deal and those who are thought to be connected with it.

T. H., in the one sympathetic letter, mites to citizen, who has defended Westbrook Pegler and Frank Kent, anti-New Deal syndicated columnists. He calls attention to Roosevelt's enemies, Hitler, Goering and Himmler. He concludes: "We must honor him for the enemies he has made."

I. W. feels that the reaction against the New Deal was occasioned by its having played polities with OPA, WPA, and PWA.

In a second letter I. H. maintains that the New Deal was a "flop" and that, with the Republican victory in the Congressional eleetions of 1946, we shall have "plenty of everything." The New Deal was "a dangerous experiment saturated with Communism" and "poisonous to our Americanism."

In a third letter I. F. asserts that the Republican victory has focussed the "eyes of the world on us." He goes on to say that:

Americans being an intelligent people have for the past 14 years gotten enough of New Deal radicalism and unsound government. Hence the Republican Party with its new responsibility of leadership must make good or it too, like the New Deal party, will lose the confidence of the people. Then all is gone.

(The New Deal featured) the powerful influence of deceptive dictators and near dictators....

(He prays that God will help us continue to) be the most porerful and influential nation - morally, socially, economically, politically, and religiously.

In a fourth letter I. W. prologues his main point with the usual references to New Deal "radicalism." His principal target this time is 
David Lilienthal wom he tags as a "100 per cent New Dealer." He lauds Senator Taft, who is leading the fight against Lilienthal's appointment to the Atomic Fnergy Commission, drawing in information about Taft's background and his merits.

T. I., who has his moral-philosophical strictures against the New Deal, organized labor, etc., mimeographed and sent to dailies throughout the country, writes an informing letter in comment upon the "spirit of greed" which motivates the New Deal and labor leaders.

New Deal borrowing amounts to "borrowing from unborn generations" and is driving us to economic collapse.

Today the spirit of greed is personified in labor leaders who won the porer and license of lawlessness by taking advantage of the dopey dues-paying dupes.

In a second letter T. Y. writes that the country needs more common sense and less self pity." our lack of common sense is seen in our giving all our resources to the world and expecting to have enough here; our expecting government subsidies but not liking high taxes; our desire for high wages and Iow prices; our desire for full employment but our making it impossible, through labor union activities for higher wages, to create a job; our wanting to be free men but our roting in a dictator, Franklin Roosevelt.

H. X. bewails the defeat of Senator Burton K. Wheeler in the 1946 elections. He can see no sense in this country's participation in World War II, and in its having granted a loan to Great Britain. Both houses of Congress are full of British sympathizers. Senator Theeler "had Iined up against him all the warmongers in America, all the C. I. O. strength which is trying to turn this country over to the Communists. . . England is now using her devilish diplomacy to get us into a war with Russia so that England, not Russia, will be boss of Europe." 
In a second letter H. X. takes J. F. Garvey to task for his criticism of H. X.'s definition of the New Deal. He (J. F. Garvey) is a ntypical New Dealer." The New Dealers, it is implied, started the War. We are too poor for another war. It is up to the Republicans to put us on our feet before we can start another war. A word of caution - "New Dealers must be watched for they are tricky."

In a third letter $\mathrm{H}$. X. accuses the Courier Journal of being "the most virulent of all the New Deal newspapers in the United States. . . It hates the old-time Southern Democrats because they are strongly for America and are not pro-New-Dealish."

In anticipating the 1948 presidential nominations, H. X. finds Senator Vandenburg too liberal. He would have Taft or Bricker.

In several letters S. G. takes up the problem of New Deal debts since 1933. Since 1865 the "country (has been) driven deeper and deeper into debt." The New Deal has been especially guilty in furthering this sort of "economic quackery" which is going to drive us into a new depression. It "played upon the chords of unselfishness to deceive the people and to attain selfish political and economic rewards for itself."

In a third letter S. G. inveighs against the New Deal's promotion of artificial scarcities in agriculture. He feels that there is something significant in the fact that Hitler rode into porer at about the same time that Roosevelt was elected. Between 1933 and 1941 President Rooserelt was fighting "American Democracy" and "free enterprise" in the same manner that Hitler was combating the two in Germany. Franklin Roosevelt recognized Russia where 10,000,000 Rus sians "had already died on the altar of freedom." - . The country wallows helplessly in the palms of irresponsible, New Deal trained, pampered strike leaders who seem to recognize no welfare other than their orm and their throttled following. 
In a fourth letter S, G. writes that we need Big Business for a big country. The Republican Party is the voice of Big Business and Individualism.

In a fifth letter S. G. applauds Taft for his stand against Lilienthal's appointment. He calls attention to alleged Communist support of Lilienthal.

Lilienthal's political inheritance is that of Eastern Europe, which many Americans justly fear, considering Eastern Europe's recent and too easy alignment with Russian Communism.

C. $O P A$ - The Cost of Living

Opinion in 1946-1947 was much more evenly divided over OPA than over the preceding topics. Possibly the reason for the strong "pro" opinion on this topic was the dramatic upswing in prices after price controls were lifted, with its day by day effect on the pocketbooks of those whose wages lagged behind price jumps.

out of fifteen letters written by writers in Groups I and II, eight are in favor of the continuation of OPA price controls.

Q. Y., after price ceilings had been lifted, called for the holding of the price line voluntarily, citing the example of Kaufman-Strauss in Louisville. He makes a plea for agreements between wholesalers, retailers, manufacturers and workers.

In a second letter Q. Y. fears a "crash landing" due to the draining of purchasing power by high prices. He accuses Congress of catering to the farm vote, in having killed OPA.

In a third letter Q. Y. calls for the ousting of the present Congress for sending President Truman an emasculated OPA bill which he couldn't conscientiously sign.

In a fourth letter $Q$. Y. urges the public to exert pressure upon OPA to roll back prices or to "force it to resign and get its hands out of Uncle Sam's pockets." 
T. H. remembers what happened during inflationary Post World War I and 1929. Anti-OPA persons, he predicts, will have another W. P.A. an which to vent their spleens in the coming post-inflationary depression.

In a second letter $\mathrm{T}$. H. directs his remarks to Hatler Johnson who had, a brief time previously, written a letter condeming the OPA. T. H. claims that the argument that production was curtailed by OPA is not borne out by the facts for the first six months of 1946. The real question, he says, was one of abnormal demand rather than one of low production.

In a third letter T. H. again directs his remarks to Hatler Johnson, asking him to make real wage comparisons between the Hoover and the New Deal eras.

X. V. finds the answer to shortages not in the Democratic and RepubItcan policies but in a "gouging conspiracy."

This is a conspiracy on the part of the producers to gouge you and me. It is a strike of the farmer who refuses to sell pork or beef, the processor who holds back for big profits, and all other manufacturers who are aiming at our economic system with poisoned policies.

We must investigate and expose. If necessary, nationalize, and return property when the offenders decide to behave.

U. N. mrites that the cessation of OPA producer's subsidies throws the cost, which had been borne by the government, directly to the consumer, which, he argues, should be the basis for a demand that taxes be reduced immediatelj. At the same time governmental expenditures must be cut to the bone. He asserts that prices are following spiraling wages.

In a second letter U. N. opposes $O P A$ on the ground that the law of supply and demand should be reestablished. "There is only bungling because we have such bureaucratic and demagogic boards and agencies. If we were free of them, then the laws of supply and demand would work." 
S. G. contends that in a nation of $140,000,000$ persons steeped for over "400" (sic.) years in freedom, with high productive power, OPA is unworkable. OPA is really responsible for high pric es in meats because it permitted grain prices to soar while holding back prices on meats to the point at which it was not profitable to keep live stock. "I predict that within less than 60 days the meat counters will be as empty again as the head of a New Deal adrocate of planned ecanomy."

In replying to a Courier Journal editorial, "The Price Problem Mr. Porter Faces," S. G. announces that he is for the business man's profit.

Any kind of OPA in America is a heavy fog that deadens initiative, engenders lawlessness, wastes time and confines the touch of imsgination to petty and personal selfishness. It is not dynamic and expansive but is withering and contractive.

In a third letter S. G. repeats the remarks made by him in his two previous letters. In scoring the OPA he writes - ... Every infraction of economics must be cast onto its neck."

T. Y. hopes that OPA will stay abolished. He attacks OPA subsidies. He mentions his "trailer home." (This last point definitely reads like a "play to the gallery" since T. Y., according to the answers on his questionnaire has a street address, and is a government statistician who claims to have had residence in Washington, D. C., for twenty years.)

We are leaving a great debt to a regimented generation. I am thankful that OPA is abolished and I hope it stays abolished. Now I can look forward to getting material to build that house I have always wanted to build.

I. W. believes that "we' re living fictitious lives." The Bible is the "greatest fact in the world." The spread of Communism and Socialism are flights from reality. We are copying both of these in the United States through OPA. "I say remove all government controls, let supply and demand rule things again." 


\section{Organized Labor}

"Organized Labor" was the most popular of the five topics chosen for this section. Twenty-eight letters were written by Groups I and II, centering upon this subject, nationally and locally. Eleven persons contributed to the discussion of "Organized Labor." It is interesting to note that three persons wrote nineteen of these letters. Twenty-five of the letters, written by eight persons, are "anti-labor."

U. N. writes that labor has fumbled in not trying to push production so that prices may be reduced. He feels that the economic demands of labor leaders may be all right but objects to "political pressure."

In a second letter U. N. holds labor to account for "sub-standard and materials." He asks - "How about it, Reuther?"

In a third letter in anticipation of a coll miner's strike U. N. warns the United Mine Workers that it may not pay since it may encourage the use of coal substitutes and the further development of hydroelectric power, as a substitute.

J. N. urges the passage of an open shop law in Kentucky, as in Virginia, in a fourth letter. He believes that such a law will "protect" the miners. "These miners are being persecuted by their own leaders; they are being brought to a state of poverty by their om labor bosses; they are being used as a pawn in a political fight."

A little more than a week later $U$. N. writes a fifth letter arging that the public own and operate the mines under civil service.

Certainly the Unit ed Mine Workers union has forfeited its stewardship. This union has been the pawn in the hands of labor exploiters long enough. The miner himself is the one who needs the protection, even more than those of us who use the coal he digs. . . If this be Communism, then make the most of it. 
In a sixth letter U. N. again blames "sloppy workmanship" for high

prices. Iabor he writes; should do work of better quality and take less

interest in the pay envelope.

In a seventh letter $U$. N. concentrates upon the efforts being made to organize public school teachers in Louisville. It is all sabotage by "commonistic leaders," he believes.

The request of the teachers for recognition of their organization by the Board of Educ ation raises the question of whether they will follow the leadership of labor unions in demands upon preparation and qualffication for more pay. There was a time when the industrial worker depended upon his preparation for more pay through practice, night study and reading. We might have reached that point in development, but force is taking the place of efficiency.

In an eighth letter U. N. finds that labor unions are "Communist led," in the main.

I use the words foreign agents, and I mean that they prove, through their ability to confuse the labor union members and their ability to raise the cost of living through work stoppages, that they serve a foreign power by causing trouble in the se United States. . . C. I. 0 . (leaders) are smart, clever and resourceful in spreading the gospel of Commonism, discontent and confusion.

T. Y. assails the "labor lobby" of "unionists and communists." "Who furnishee the money to pay for these hirelings? The dopey dues-paying dupes. Fortunately most Congressmen know."

The questions of the hour, according to T. Y. in a second letter, are: (1) How can we free workers from labor unions? (2) How can we pay the national debt? (3) How can we get "appointed crackpots and unfriendly aliens" out of the government?

Now don't you think it is time we got back to the good old successful American system instead of continuing the experimenting with every European plan of dictatorship? 
In a third letter T. Y. writes of the "foreign influence of hate and greed" which motivates our labor movement. Self pity and greed cause strikes, writes T. I. Although 50 per cent of Americans are church members we may be docmed to a new "Dark Age" by the 50 per cent who are "half Christians" and who may be worked upon by some other nation.

In a fourth letter T. Y. asserts that there can be no peace among nations until there is peace among individuals, who are informed by wisdom instead of by greed.

After this brief moral-philosophical introduction T. Y. gets to the point.

If union members are given a chance to remove their top union bosses, they would probably rote according to their own greed instead of their wisdom because, like their union bosses, they also have more greed than sense. Collective bargaining usually means collective greed. . . . An open shop would give individuals a chance to use what wisdom they will.

In a fifth letter T. Y. urges that the Wagner Act be repealed. A majority of the workers in the C. I. O. and the A. F. of L., he confidently asserts, don't want it anyway. They are tired of "paying tribute for the privilege of working."

Because of the present law of enforced submission to gangsters, the people elected a Congress that is under no obligation to the underworld, and the new Congress should abide by the will of the people and repeal the Wagner Act that protects gangsters, and pass a law that will protect the workers from being organized.

In a sixth letter T. Y. says that the closed shop is not morally right and that he is for a "100\% open shop" (which the reader must be beginning to suspect by this time).

If the dues-collecting masters had one iota as much sympathy for the workers as they pretend, they would not force them to quit their jobs for long periods every time the master desired some publicity. 
In a seventh letter T. Y. expresses alarm over "portal to portal" pay which, he asserts, will ruin both employers and employees.

The combination of the C. I. O., Communists, A. F. of I. and other similar egoists are forcing this country into a dictatorship. . . If the dopey dues-paying dupes had any foresight or common sense, they would orerthrow these labor leaders now.

T. Y., in an eighth letter, denies that there is a Mright to strike." (It is an)...

unethical idea that labor has an inalienable right to strike. A person wilfully on strike is just plain greedy.

The average employee, however, is forced to strike by the union boss who hopes to gain more personal power and money for himself. The clased shop forces the average employee to either strike or lose his job.

V. Z. N. writes about labor with a moralistic and literary emphasis. Nathaniel Hawthorme would not have chosen to become a labor leader because he would have disdained to make "a luxurious living by men's mrongs and discontents."

In a second letter V. Z. N., who has been very much agitated by the activities of the teachers' union in Loulsville, sighs for the good old days when Americans had pride in workmanship. For literary garnishing she uses a story about a "post war umbrella" by William Dean Howells. Further - "Wake up America. The path of least resistance is the path of degeneration.' I have that from a professor of Botany." She also cites a "university professor of English" to prop up her argument.

In getting down to what she had, in her second letter, approached less directly, the appearance of representatives of the teachers' union before the school board to request recognition, she first established that she has been a teacher herself.

She doesn't like striking to "force demands." "The code of the profession forbade it." 
A person has dignity in proportion to the inherent worth and dignity of his or her character and service.

S. G. writes in comment upon William Green's (president of the A. F. of L.) statement that if labor is to be hamstrung by restrictive legislation it will "commit suicide by going communistic."

This, to S. G., means chaos and "nihilism." Apparently he misunderstands Mr. Green for he (S. G.) sees no sense in American labor's embracing Communism since it leads to "suicide." He asks Mr. Green to contrast Labor in Russia with Labor in capitalistic America.

X. V. directs his letter to the regional director of the C. I. O. and to "common sense" in moralizing about "labor's due."

T. H. condemns the United Mine Workers because it is "run from the top." He feels that Lewis's strikes are not always necessary, and suggests that some of them might be worked out over the conference table.

I. Y., former Inspector of WeIding at the Dupont Powder Works, argues against the closed shop..

Z. S. writes a letter of commendation for President Truman for stopping the railroad strike and "saving the country."

Q. Y. feels that the small pay of Congressmen does not secure men of sufficiently high calibre to work out fair measures for capital and labor.

$X$. $X$. believes that the coal strike may be a blessing since it makes the country realize how inadequate our labor-management set-up is, and how great the need is for compulsory arbitration. He expects Congress to pass laws to protect people from both Labor and Management

\section{E. Drinking and Gambling}

Letters written on "Gambling and Drinking" in Groups I and II numbered twenty-one of which twelve were "anti;" seven, "pro;" and two "neutral." Four 
persons mrote letters expressing prohibitionist sentiments and one person accounted for the opposition letters.

One of the most common sentiments expressed was, that in view of paper shortages, liquor ads should be eliminated. V. Y. 2 accounts for the first letter on this topic (See p. 29 for background).

In a second letter V. Y. 2 states that after having seen the effects of alcohol on patients at Eastern State Hospital (a mental hospital) where she is an attendant that she can't see how "a newspaper can on one page talk for decency and then on another page print an advertisement that pictures the romance of alcohol, to induce young people to drink."

In a third letter V. Y. 2 insists that Sam Morris (a noted "dry") was forbidden time on the radio but that "atheists, communists, liquor distillers and dealers" are given time freely. Mr. Morris's work is "proof for God" since he and "so many people try for something beyond themselves."

V. Y. 2's fourth letter re-states the points raised in the foregoing three.

T. X. mites two letters opposing liquor advertising. He himself is the publisher and editor of a small newspaper. According to T. X., distillers and saloonkeepers don't hire drunkards but they make them. The main damage of liquor must be stated in terms of broken homes, crime, etc. The yearly cost of liquor advertising, he estimates, is $\$ 75,000,000$. "I am proud that my paper will not accept such trash as badly as I need the money."

In a third letter $T$. $X$. indicates that he would eliminate drunkenness by levying fines on saloonkeepers. "Here is a plan to eliminate drunkenness the greatest curse of Mankind."

T. D. feels that gambling, Public Enemy No. I, is on the rampage 1ocally. Citizens should work through the Louisville Christain Civic League 
and the public schools to combat the menace. "In destructive force and total deadly effect it is above the legalized liquor traffic, its twin brother."

In a second letter $T$. D. holds that the bad social effects of gambling stem from the "something for nothing" philosophy it engenders.

In his third and fourth letters T. D. directs his remarks to "Beer Barrel" and Mr. Bow, both of whom are defenders of the "Wet" position. He contends that wets worked for repeal through building "a nation-wide propaganda front, using deception, coercion and distortion." The main business of beverage alcohol distillers, even daring the war, was to tum out booze.

The citizens working for a sobriety-promoting, thriftpromoting, protective prohibition law do intensely hate the whole parasite liquor industry. . . We are not working for ourselves.

$X$. X. wishes to call the attention of law enforcement officials to the violation of the law forbidding slot machines in New Albany. He asserts that they were put into operation again after the "clean-up." The "law should be enforced."

V. Y. writes two letters urging that the sale of alcoholic beverages be regulated by the state. He objects to Sam Morris's "all or nothing" point of view. He feels that the public is in error in believing that the bartender has angthing to do with the conduct of its sons and daughters.

Why don't the parents raise their children so they won't want to go into saloons? Why don't juvenile courts punish the parents who take their children into bar rooms?

T. H. states that he is neither an ardent dry nor an ardent wet. He, however, objects to the accusation of the "dry" faction that wheat is being wasted by distillers on the ground that there is an oversupply.

In a second letter $\mathrm{T}$. H. answers a letter by a Mr. Jackson who has argued that Kentucky ranks low educationally because its liquor bill is high. He requests comparative data on states of high educational status. 
In a third letter he counters the contention that liquor is "tho greatest menace to civilization" by asking why non-using Mohammedan nations rank so far behind "Anglo-Saxon" ones.

He asks, in a fourth letter, for evidence for "anonymous's" contention that actors and singers never drink.

T. H.'s next two letters recall the difficulties experienced by the country under national prohibition, particularly the growth of organized crime. He objects to Mrs. Bopp's reference to the St. Valentine's Day massacre as harmless except to those involved, on the ground that it undermined the law of the land" and the "right to jury trial."

Moreover, in his opinion, when the prohibition amendment was voted out, national prohibition, as an experiment, was established as a failure. It mast be abendoned in favor of a way that may succeed.

In his sevanth letter T. H. answers G. C. Whitely who has accused "wets" of political under-handedness in getting the eighteenth amendment repealed. What about the dry front headed in Washington by Wayne B. Wheeler? The eighteenth amendment was adopted by deception "when the boys were overseas." He concludes by commending T. C. Vaughan for calling attention to the prevalence of bootleggers in Kansas, Oklahoma, and Mississippi.

\section{F. Comment}

The letters in the foregoing section are interesting for several fairly consistent patterns which may be abstracted from them.

The most strikingly consistent pattern is that of political, social and economic conservatism, especially on the topics, Communism, Labor, the New Deal and Prohibition. For example, all but one of the writers are convinced that communists should be handled roughly. They are either "outside the law" or 
should be treated as a source of danger to domestic peace and tranquility. The use of the term "communist" is inclusive enough, often, to cover all but those whose opinions do not diverge substantially from the letter writer's. One gets the impression that these writers are intolerant of minority viewpoints even to the point of desiring to deny these minorities their basic civil liberties.

The writers of these letters seem to be conformists with a rengeance. They make it clear that they are aligned with the angels. They are the advocates of "God," "Religion," "Free Enterprise," "Democracy," Americanism," and "the Right." Being, of course, indubitably in the "right" their statements of opinion are made with scarcely a single qualification. The most extreme opinions are rendered as though they were facts which called for no further enquiry.

Thus, in the place of informed analysis one finds "middle class" moralizing, and the setting forth of preconceptions embellished with an insistence upon the moral rightness of the writer's position. Judgments are made in blacks and whites, as though this approach to the subjects handled were the only valid one. One suspects that the "factual" material occasionally submitted is just window dressing which has little to do with the point of the arguments, in most cases.

A frequently used device is that of the "hate symbol," representing trends and movements to be feared. The names, Franklin D. Roosevelt, Henry A. Wallace, Stalin and John L. Lewis cropped up frequently in this connection. Disliked morements and trends are associated with "bad men" and the wrath of the writer becomes more personal and more acrimonious.

For the writer of this thesis, the speculation is inescapable that these reader letter writers are writing out of a generalized uneasiness in which certain groups, persons and movements are selected as convenient and publicly 
defined "fair game." Their small grasp of and their apparent lack of interest in the facts of the situations about which they write contrast vividly with their perceptions of "threats." The phenomenon described here is a familiar one to sociologists and caltural anthropologists to whom it is known as "scape-goating."

In the fourth chapter of this thesis the orientation of the letter writers, as evidenced by their letters are related, where relevant, to the personal data concerning the letter writers set forth in most of Chapter III. 
Chapter IV

Summary and Conclusions 
Chapter IV

Summary and Conclusions

The writer of this thesis set out to examine the backgrounds and the letters of forty-four writers to the Louisville Courier Joumal "Point of View" column with the intention of determining whether or not there were significant traits in the backgrounds, motivations, and writings of "chronic" or "most frequent" writers and "frequent" writers (Groups I and II). The source materials for this study were the bound opies of the Courier Journal for June 1, 1946 May 31, 1947, and a questionnaire requesting the information classified and interpreted in chapter III, sections 1-4.

Statements of policy, with respect to reader letters, were received from twelve daily newspapers of large circulation for comparison with that of the Courier Jourmal. This comparison suggested that the Courier Jourmal published a significantly larger proportion of letters received from readers than do all others but the Birmingham News-Age Herald. A further conclusion was that it is probable that there is a rather close correspondence between the frequency at which the subjects of this essay submit letters and the frequency at which their letters are published, since an effort is made, finally, to publish all letters which do not disqualify themselves on the grounds listed on page 5 of this essay, and since the factor of space limitation apparently does not demand that the editor-in-charge of the "Point of View" column exercise so drastic a selectivity as seems customary in eleven of the dailies queried. The relevance of the above points to the subject of this thesis is that it is probable that the letter columns of the Courier Jourmal are a fairly accurate reflection of the rates of participation of reader letter writers and 
58.

of their opinions. Thus this thesis is very likely a study of the letter writer rather than the published letter writer, as would be true if the source materials were the letter columns of a daily employing a more restrictive policy, as seems to be the case with eleven of the twelve other newspapers surveyed in Chapter II, section 2. This, doubtless, accounts for the rather trivial, sometimes foolish, nature of a large proportion of the letters printed in the Louisville Courier Journal. "Point of View" columns.

Data on the ages of "Point of View" letter writers indicate that letter writers in all the three groups (based on letter writing frequency) tend to fall in the middle and older age-groups. The average writer in these groups ia about 59 years of age.

Reader letters in these three groups are overwhelmingly from the white collar, business and professional classes and their writers are overwhelmingly male. The white collar class predominates in Group I ("chronic" or "most frequent" writers) and the business and professional classes in Group II ("frequent" writers) and Group III ("moderate" writers). Other broad occupational groups have contributed relatively few writers. It must be concluded, then, that these groups of writ ers are not representative, in age, sex, and occupation, of the population of Louisville or of the population at large.

With respect to church affiliation or preference, the forty-four letter writers indicated "protestant" leanings to the extent of 70 per cent. 24 per cent answered "none." If those answering the question "Catholic" are included these letter writer preferences indicate a rather strong attachment to "Fundamentalism," doctrinally. This would seem to be particularly true of Groups I and II, in the order given.

Given the probable large Roman Catholic minority in Louisville, and the fact that 50 per cent of the writers are residents of Louisville, the Catholics are under-represented in these groups of writers. 
Groups I and II are strongly "Republican" in their political attachments, as compared to Group III. However, "political party affiliation or preference," if these are checked with the content of reader letters, seem to be of little use as indices to the conservative-liberal-radical orientation of writers. This is true also of "Independents." Letter writers, regardless of formal political party affiliations or preferences, are, with few exceptions, conservative in their political philosophies.

On the point of formal education the "Point of View" writers are probably superior to the general population. The rather large percentage of professional persons, of course, pushes the mean and the median high. These are both 13 years, one year mare than high school graduation. The "chronic" letter writers rank below "frequent" and "moderate" letter writers in this regard, and the latter two groups take first and second places in the order given.

However, few writers in any group give evidence of having had formal educational backgrounds peculiarly qualifying them to write in an informed way about the subjects they pursue in their letters.

The data on "marital status" indicate that persons in Group I conform much more closely to traditional norms than those in Groups II and III, in which "divorced," "divorced and re-married," and "separated" persons constitute 33 and 38 per cent, respectively, of these groups.

The letter writ ers in the three groups are overwhelmingly Native-WhiteAmerican" of old stock. The two exceptions are a "Swiss" and a woman answering, "Negro-american."

Ninety-two per cent of the letter writers in Group I ("chronic" or most frequent") are residents of Kentucky and sixty-seven per cent, of Louisville. Writers in Groups II and III are more frequently out-of-state residents or are from Kentucky but not from Louisville. 
It is established in Chapter III, Section 2, B, that 36 per cent of the forty-four letter writers have had selections published in media other than letters-to-the-editor columns. Of the three groups, Group I has used these media least. Groups II and III rank ahead of Group I, in the order given. Thus persons in Group I depend much more upon "letter writing" than do persons in the other groups which may, in part, account for the greater frequency of their participation in letters-to-the-editor colurms.

Persons in Groups II and III read regularly more newspapers other than the Louisville Gourier Journal-Pimes than persons in Group I. The striking feature of the listed newspapers, other than the Courier Journal-Times, is the absence of dailies with liberal political reputations, particularly in Groups $I$ and II.

Writers in Groups I, II and III read three magazines regularly, on the average. These magazines are, except for Group III, predominantly popular ones, with Reader's Digest, Saturday Evening Post, Time, Life, and Collier's leading. These five magazines account for 44 per cent of the magazine readings of the "Point of View" writers. Few writers read magazines with the reputation of being addressed to the more serious-minded reader, such as Harpers, The Nation, Atlantic Monthly, and the like. "Digests" of one sort or another account for 25 per cent of the letter writers' readings. Letter writers, then, read conservative popular magazines.

Twenty-nine of the letter writ ers professed to having read no books of fiction for the last five years, which they could list. Only seven persons listed more than two titles. Most of the books listed were not of such character as to provide either information or insight into the problems of which letter writers write. With respect to the frequencies with which members of the groups listed fiction books, the groups rank in the following order: II, III, and I. 
Fifteen of the letter writers (33 per cent) read no non-fiction books. Fourteen of these do not read fiction either. Group I shows the greatest weakness on the above two points, with Group III following and Group II with the best showing. The non-fiction books read by writers are not such as to contribute to their understanding of the problems discussed in their letters. There are five exceptions to this generalization. Two of these persons are in Group III. Letter writers in all groups depend overwhelmingly on popular magazines and newspapers for their informational and interpretative backgrounds. These tend to slant their coverage of contemporary happenings to the economic, political, and social right. The reading of pertinent books and recourse to expert opinion are negligible factors in the backgrounds of "Point of View" writers. This is particularly true of Group I. Group II has the most impressively strong record here.

A strong majority of letter writers believe that their letters "do some good" and that "the time and energy expend ed in their writing" are justified. Writers in Group I seem to express a greater pessimism on this point than writers in the other groups.

With reference to the above, a number of letter writers either stated directly or implied that an important satisfaction in writing was the opportunity it gave to "blow off steam." Others "blew off" in writing answers to this question (See the statements of V. Y., S. G., V. Y. 2, and T. Y.). The high proportion of "anti" this or that letters, some of which are discussed in the section on the five most popular topics, gives support to the thesis that "Point of View colums are social safety valves. Indignation and heavy-handed acrimony are startlingly frequent elements in the contributions of these writers to the Courier Journal reader letters column. 
The heaviest concentration of reader letters occurred in "National Affairs" where 78.5 of 132 letters were on three topics, all of which are discussed in the "most popular topics" section. The distribution of these and many other letters in "International and Foreign Affairs" and in "General" indicates that letter writers are much more interested in persons and activities that are more than local or state-wide in their scope.

Group II seems mach more interested in "Intermational and Foreign Affairs" than the other groups; Group III, in "National Affairs."

Individuals in Groups I and II are decidedly more prone to write on favorite topics with greater frequency than are persons in Group III for 30.8 per cent of their letters are written on the five most popular topics, with some few writers doing yeoman work.

The most popular topics are those which seem to be most highly charged, emotionally, for "Point of View" letter writers. There is a liberal amount of free association on these topies, in which writers identify Communism, Labor, the New Deal and OPA, and, in one case, Drinking, with one another.

Writers in Groups I and II seem to hold to a "devil theory" of contemporary history, and view economic happenings and political moves which they don't like as sinful departures from God's way or the "natural law of supply and demand" or as the results of the malign influence of "the foreigners," "the oriental mind" or whatever you will. Russia is spoken of by several as "the enemy of the human race." Communism places those who adhere to it "on the outside of the lowest order of the human race."

The New Deal was "a dangerous experiment saturated with Communism" and "poisonous to our Americanism." New Deal administrators were "dictators." New Deal borrowing will lead to economic collapse. 
One writer equates Communism, the New Deal and the C. I. O. and concludes that England is attempting to get us unto a war with Russia, with her devilish diplomacy." our government is full of "British sympathizers." Roosevelt was fighting "American Democracy" and "Free Enterprise."

Those who argued for the continuation of OPA held that shortages and high prices are the results of abnormal demand and the attempts of retailers, wholesalers and manufacturers to profiteer. The ultimate results of this activity, they predicted, will be the draining of purchasing power and a deflationary tail spin, following the pattern of post World War I and 1929. Those opposing OPA apparently believe that the American economy is still based upon a competitive price system and that the taking away of OPA controls will bring into operation, automatically, the nlaw of supply and demand." This is the same sort of world $\mathrm{Mr}$. Hoover imagined himself to be living in when he spoke of the "natural forces of recovery" re-asserting themselves, in the early years of the depression. Thus, in an era in which the "administered price" predominates in many of the key areas of economic activity "Point of View" writers generally hold to classical economic concepts which seem to have small counterpart in the present-day world of economic reality.

The overwhelming majority of the letter writers are "open shop" advocates on the grounds that a "closed shop" is an imposition on the worker, that he is"forced" to join the union, that he needs to be "protected" from labor leaders. Labor, the New Deal and Communism are frequently linked here. Strong objections are raised to Labor's political activity. High prices are held to be due to the pressing of unions for higher wages and the shoddy work that they turn out. Writers in Groups I and II identify themselves closely with the employer point of view though many are "self employed." 
Those who are not vehemently "anti-labor" stress the need for improved labor-management-techniques and urge compulsory arbitration under federal auspices.

A majority of those who write letters on the subject "Drinking and Gambling" express the prohibitionist point of view. Drunkenness is the "Greatest Menace to Civilization." The fight against "liquor" is being waged by "sobrietypromoting," God-inspired citizens who are devoting their services to a cause greater than themselves. Distillers, retailers, atheists, communists, bartenders and incompetent parents are named as those behind the "wet front."

T. H., the only person writing from the "wet" standpoint in Groups I and II, maintains that the national prohibition law was adopted at the behest of a dry lobby using intimidation and underhanded tactics to get it passed, that its repeal proved that it was a failure, that it encouraged and encourages (in dry states) bootlegging and organized crime.

The conclusions of this study may be stated as follows:

(I) Letter writers in Groups I and II are-

(a) overwhelmingly in the middle and old age-groups;

(b) male in sex, predominantly;

(c) more conservative in their viewpoints towards marriage and divorce if their collective marital statuses are a reliable index to their attitudes, than those in Group III or, presumably, in the general population;

(d) conservative religiously, if the writer's inference concerning the meaning of their denominational affiliations and preferences is permissible;*

(e) conservative, politically, regardless of political party affiliation or preference, or profession of political "Independence";

(f) probably above average in formal education attainment, averaging one year more than high school graduation (12 years);

(g) "native white Americans," predominantly;

* The religious content of reader letters bear out this point consistently. 
(h) residents of Louisville and of Kentucky, in great majority, and have lived in the localities in which they now reside for an average of about 18 years;

(i) drawn from the white collar, business, and prom fessional classes, overwhelmingly.

(2) The writers in Groups I and II are not representative of the general population. It is highly probable that they are not representative of the populations of the localities in which they reside and of reader letter writers in general. The above points substantiate these conclusions. Writers in Groups I and II are drawn from the white collar, business, and professional classes and, an political and economic questions, tend to adumbrate the conservative opinions of the more rocal of the organized employer groups (such as the Chamber of Commerce and the National Association of Manufacturers).

(3) The Louisville Courier Joumal "Point of View" column can be described as a "social safety valve." This thesis is supported by:

(a) the statements of the reader letter writers themselves in the questionnaire, as summarized in Chapter III, section 4;

(b) the "against pattern" evidenced by the positions taken by writers in their letters* and their mode of argumentation;

(c) the hotly contentious nature of the letters. These letters do not represent, usually, reasoned, logical approaches to problems but highly emotional, irrational reactions to practices and policies which, more often than not, seem not to be clearly and fully understood by their writers. Occasionally, the letters are abusive of the persons to whom they are supposed to be answers.

(4) The backgrounds of writers in Groups I and II, as evidenced by their magazine, newspaper, fictional, non-fictional readings and present occupations and presumed academic training, are not such as to give the writer mach

* If anti-Russia, New Deal, OPA and Labor letters and "prohibitionist" letters are totalled and compared with those expressing opposing sentiments, the ratio is about 4-1. It mast be stated that some, though a smaller proportion of the total, of the opposing letters evidence this "agsinst pattern." 
confidence in their juagments on tise questions about which they write, even if he had never seen any of their letters. The initiel doubt as to whether the writers have sufficient background and information to write with authority is strongly reenforced by a reading of their letters over a period of time.

(5) It is the personal conclusion of this writer that the "wide open" "Point of View" ox "lctters-to-the-editor" colums, if their justification is that they are to inform and to afford opportunities for the expreasion of reasoned differences of opinion for the benefit of the reader public, should be cerefully exanined to determine whether or not they are making a contribution to this end, or are simply, to a large extent, providing a forum for the airing of misconceptions, without persistent explanation and correction on the part of those who publish them. Many of the letters excerpted in Chapter III, section 6, raire little pretense to reasoned argument but are compounded of dogmetic essertions only. The aforesaid letters are not at all un-typical.

Aside from the foregoing, the writer is willing to concede thet such colums may be useful in supplying media through which writers ney "blow off steam."

The writer feels that it is necessary for him to state that this thesis would have been greatly strengthened if there had been available personel data for the general population, for Louisville and vicinity, and for groups of representative letter writers perticipating at lower retes than those persons in Groups I, II, and III. Until this materiel is avsilable statenents regarding the "peculiar traits" of "chronic" and "frequent" letter writers are of dubious value.

A nuraber of interesting research problems were raised for the writer by this thesis. There is the problem of the extent of the public influence of widely read "Point of View" colurns.

It would be interesting to inquirs into the possible differences in the points of view of witers participating at different rate-levels during such 
contrasting periods, for example, as that of friendly Anericen-Pussian wertine collaboration and the period of Post World War II antegonisn. What efrects, if anj, do such changes in the social and politicel atmosphere heve upon letter writers? How might changes in opinion, if there ere wuch, be retionalized? Other studies might be made of "ethnocentrisn" in reader letters, or of the views of reader letter writers on "race" or any number of other such topies.

Are reader letter miters consistent in their attitude patterns, in treating a varied assortment of subjects? How freguently do opinion patterns tend to be linked?

It would be interesting to investigete end to determine whether or not certain attitudes are significantly correlated with the positions of witers in the occupetional structure and in the social class system.

A significant problen might be thet of editorisl policies and positions and reader letters. Is it possible that a liberal policy will evoke letters, predominantly, from conservatives whereas the reverse is true when the newspaper is editorially conservative?

Always, the miter believes, it should be kept in mind that, until it is proved otheruise, expressing oneself on peper may set into motion a process of selection, and that this realization should inhibit the premeture extending of generalizations on the part of the investigator. Hany persons are inclined to regard expressins themselves in miting as poinful and to be avoided, whenever possible. 
Appendix 
68.

Table XIV

Letter Writers and Their Writing Frequencies for June 1, 1946 - May 31, 1947 Group I

Code Initials Number of Ietters-June 1, 1946-Nay 31,1947

X. A.

I. IT.

V. Y.

S. G.

O. Y.

X. V.

T. Y.

T. D.

U. N.

H. X.

T. H.

Q. S.

G. G.

Y. V.

Q. Y.

T. X.

X. $M$.

V. N.

23

21

20

.

19

18

17

17

16

15

14

12

S. W.

U. N. ?

H. V.

V. Y. 2

V. Z. N.

Q. 2.

Z. S.

Q. D.

I. S.

$\mathrm{X}$. X.

G. U.

Z. 0 .

Z. I.

H. Y.

X. N.

Z. X.

I. Y.

Y. H.

K. N.

S. Z.

S. D.

X. Y.

0 . S.

N. N.

O. N.

U. $T$.

11

11

Group II

10

10

10

10

9

9

9

8

8

7

7

7

6

6

7

Group III

5

5 
Trable XV

Age-Group, Occupetion, and Church Afrilietion or Preference of Letter Mriters

Code Initials age-group

T. A.

I. T.

V. Y.

S. G.

O. Y.

$X . V$.

T. $Y$.

T. D.

U. N.

H. X.

T. H.

G. S.

G. G.

Y. V.

Q. $Y$.

T. X.

X. Y.

V. N.

S. T.

U. ग. 2

H. V.

V. Y. 2

V. Z. I.

Q. 2.

Z. S.

G. D.

I. S.

X. X.

G. U.

Z. 0 .

Z. I.

H. Y.

X. II.

Z. X.

I. $Y$.

Y. H.

I. N.

S. Z.

S. D.

X. Y.

Q. S.

N. N.

O. N.

U. $\pi$.
55-59

65-69

$50-54$

50-54

40-i4

65-69

45-49

$50-54$

55-59

65-69

55-59

40-44

$75-79$

$60-54$

65-69

$35-39$

$70-74$

$50-54$

$60-6_{4}^{4}$

$45-49$

$65-69$

$65-69$

$65-60$

$55-59$

$80-24$

$75-79$

$70-74$

$45-49$

$45-49$

$50-54$

45-49

65-69

$55-59$

$45-49$

$70-74$

45-49

$60-64$

$85-89$

65-69

$65-69$

$65-69$

$70-74$

$35-39$

$40-4.4$
Group I

\section{eccupation}

railroed clerk

farmer

Saiesinan

life ins. scles.

clerk-fed. Govt.

sales promotion

govt. Stitisticien

ninister

menufecturer's agent

ettomey

inspector

office arneger

fermer, merchent

Grovip II

"supervisor, econoxics"

merchant

newspaper publisher

electrice a entines

retired

none

iserchent

b]3. contractor

prectical rumes

retired teacher

persomei hen

shipino cloris

retirea

atcormey

cttomey

Group IIT

painter

insurance

former policewonin

proi. anti-proinib.

auctioneer

bookkeeper

civil engineer

industricl rl. est.

barber

life insurance

traficic ingr.

retired frarine

fermer

retired teacher

C. P. A.

teacher church afsiliation ox pref.

Methodist

nletiodist

Presbyterian

Beptist

Catholic

None

Beptist

Beptist

Beptist

Disciples

rone

Cetholic

Beptist

Disclples

Beptist

United Brethren

Presbyterian

Beptict

Fiscoles

Tone

Disciples

Deptivt

Episcopel

Beptist

7000

Prosbuterian

Episcopel

nethocist

Presbyterion

Congrezationel

Protestant

?

Methocist

Catholic

None

Disciples

"Diest"

Fpiscopal

None

None

Beptist

Ipiscopal

Unitarian

Baptist 
Table XVI

Political Party Affiliation or Preference, Formal Education, and Merital Stetus of Letter Writers

Group I

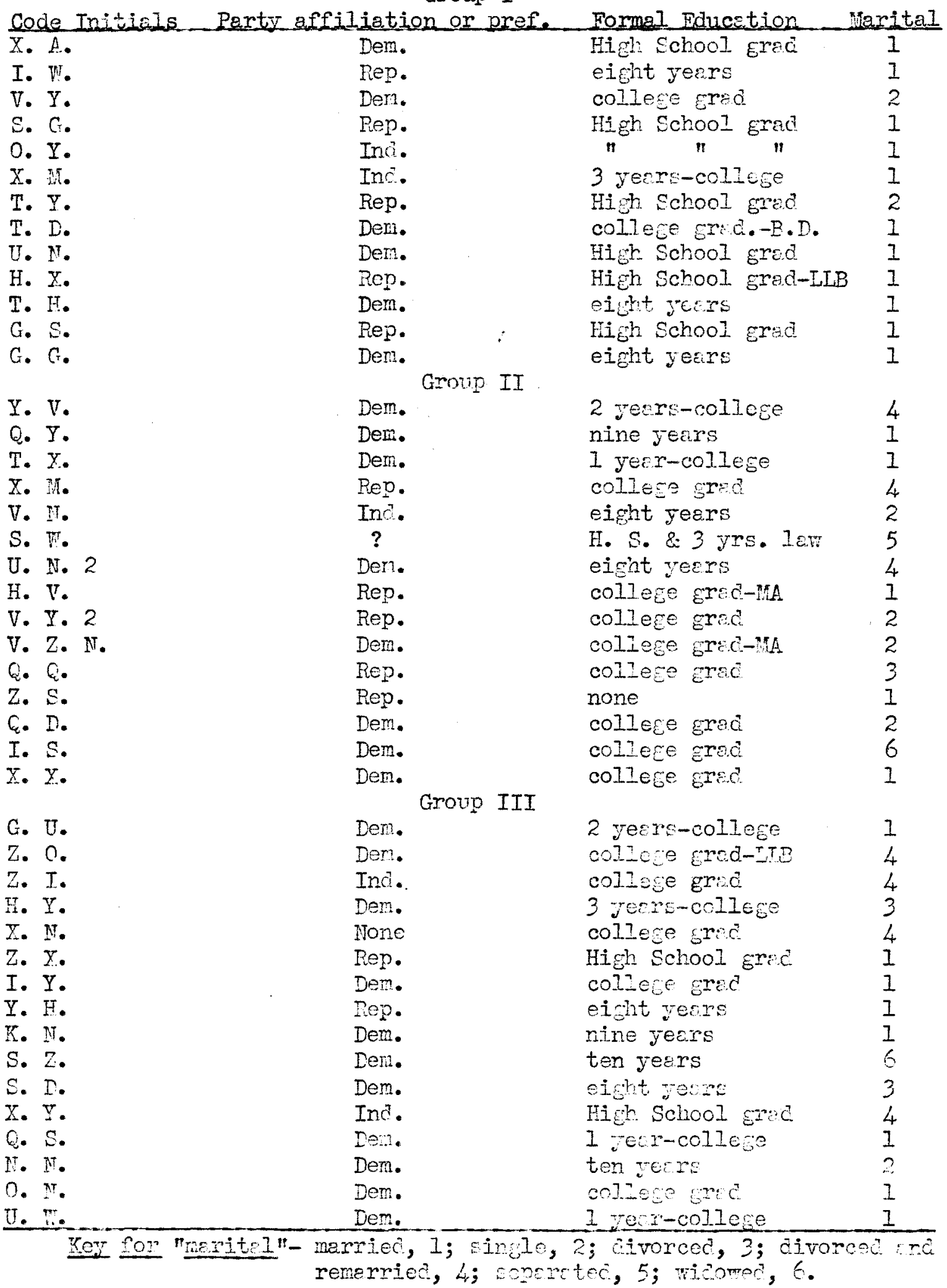


Table XVII

Nationality, Residence, and Length of Residence of Letter Writers: Group I

\begin{tabular}{|c|c|c|c|}
\hline Code Initials & Nationality & Residence & Length of Res. (in city) \\
\hline X. A. & Swiss-Am. & Louisville, Ky. & 16 years \\
\hline I. W. & American & Perryville, Ky. & 25 jears \\
\hline V. $\mathrm{Y}$. & "Gentile" & Lourisville, Ky. & 27 years \\
\hline S. G. & English-Am. & Paintsville, $\mathrm{K} y$. & 24 years \\
\hline $0 . \bar{r}$ & American & Louisville, $\mathrm{Ky}$. & 3 years \\
\hline $\bar{x} . \overline{\mathrm{V}}$. & American & Louisville, Ky. & 6 years \\
\hline T. Y. & American & Washington, D. C. & 20 years \\
\hline T. D. & English-Am. & Louisville, $\mathrm{Ky}$ & 6 years \\
\hline U. N. & Fnglish-Am. & Louisville, $\mathrm{Ky}$. & 5 years \\
\hline H. $\mathrm{X}$. & American & Burkeville, Ky. & 67 years \\
\hline T. H. & American & Louisville, Ky. & 3 years \\
\hline Q. S. & Irish-Am. & Louisville, $\mathrm{Kg}$. & 7 years \\
\hline G. G. & "Anglo-Saxon" & Murray, $\mathrm{Ky}$. & 25 jears \\
\hline & Group $I$ & & \\
\hline Y. V. & "white Am." & Tulsa, Okla. & 10 years \\
\hline Q. Y. & American & New Albany, Ind. & 1 year \\
\hline T. X. & American & Hardinsburg, $\mathbf{B y . ~}$ & 10 years \\
\hline X. & American & Louisville, $\mathrm{Ky.}$ & 35 years \\
\hline V. N. & American & Bagdad, $\mathrm{Ky}$ & "a lifetime" \\
\hline S. W. & "Am., thank Godı" & Louisville, Ky. & 10 jears \\
\hline U. N. 2 & American & Wayland, $\mathrm{Ky}$. & 30 years \\
\hline H. V. & American & Lexingt on, $\mathrm{Ky}$. & 21 years \\
\hline V. Y. 2 & American & Glasgow, $\mathrm{Ky}$ & $?$ \\
\hline V. Z. N. & American & Louisvilie, Kу. & 59 years \\
\hline Q. Q. & Dutch-Am. & Frankfort, $\mathrm{Ky}$ & 2 years \\
\hline Z. S. & "Am. Ist., last..." & Elizabethtown, $\mathrm{Ky}$. & 18 jears \\
\hline Q. D. & American & Bowling Green, KJ. & 25 Jears \\
\hline I. S. & American & Louisville, $\mathrm{Ky}$. & 2 years \\
\hline $\mathrm{X} \cdot \mathrm{X}$. & American & Louisville, Ky. & 12 years \\
\hline & Group I & & \\
\hline G. U. & American & Floyd Knobbs, Ind. & 12 years \\
\hline Z. 0 . & American & New York, N. Y. & * \\
\hline Z. I. & Negro-Am. & Louisvilie, Ky. & 12 years \\
\hline H. $Y$. & Fnglish-Am. & Louisville, Ky. & 18 years \\
\hline $\mathrm{X} . \mathrm{N}$ & Sc.-Irish Am. & Louisville, Ky. & 5 years \\
\hline Z. X. & American & Louisville, Ky. & 5 years \\
\hline I. Y. & "100\% American" & Jeffersonville, Ind. & 7 years \\
\hline Y. H. & Sc.-Irish Am. & Louisville, $\mathrm{Kg}$. & 10 years \\
\hline $\mathrm{K} . \mathrm{N}$. & English-Am. & Morganfield, Ky. & 60 years \\
\hline S. Z. & American & Witchita, Kas. & 40 years \\
\hline S. D. & American & Jeffersonville, Ind. & 22 years \\
\hline X. Y. & Sc.-Irish Am. & Louisville, $\mathrm{Ky}$. & 56 years \\
\hline Q. S. & American & Taylorsvilie, Ky. & 29 years \\
\hline N. N. & American & Louisville, Kу. & 10 years \\
\hline 0. N. & English-Am. & Louisville, Ky. & 5 years \\
\hline U. & English-Am. & Louisville, Ky. & $6 \frac{1}{2}$ years \\
\hline
\end{tabular}


Table XVIII

Magazines Read by Letter Writers

Magazines

Combined Groups Group I Group II Group III

Popular

$\frac{30}{6}$

American

Saturday Evening Post

Coronet

Iiberty

Country Gent leman

Ladies Home Journal

$\begin{array}{rlll}4 & 2 & 1 & 1 \\ 11 & 4 & 6 & 1 \\ 2 & 1 & 0 & 1 \\ 4 & 1 & 2 & 1 \\ 2 & 0 & 1 & 1 \\ 1 & 0 & 0 & 1\end{array}$

\begin{tabular}{lcccc}
\hline News Magazines & 19 & 6 & 5 & 8 \\
\hline U. S. News & 3 & 2 & 1 & 0 \\
World Report & 2 & 1 & 0 & 1 \\
Klipinger News & 1 & 1 & 0 & 0 \\
Newswrek & 3 & 0 & 0 & 3 \\
U. N. Weekly & 1 & 1 & 0 & 0 \\
Time & 9 & 1 & 4 & 4
\end{tabular}

\begin{tabular}{lcccc}
\hline Digests & 31 & 8 & 12 & 11 \\
\hline Reader's Digest & 25 & 7 & 10 & 8 \\
\hline Everybody & 1 & 1 & 0 & 0 \\
Magazine Digest & 3 & 0 & 1 & 2 \\
Onmibook & 1 & 0 & 1 & 0 \\
Readers Scope & 1 & 0 & 0 & 1
\end{tabular}

\begin{tabular}{lllll}
\hline Science Magazines & 7 & 2 & 3 & 2 \\
\hline National Geographic & 4 & 2 & 0 & 2 \\
Sci. American & 1 & 0 & 1 & 0 \\
Sci. Monthly & 1 & 0 & 1 & 0 \\
Sci. Newsletter & 1 & 0 & 1 & 0
\end{tabular}

\begin{tabular}{lcccc}
\hline "Picture" Magazines & 16 & 3 & 8 & 5 \\
\hline Look & 5 & 1 & 4 & 0 \\
\hline Iife & 8 & 2 & 4 & 2 \\
Ebony & 2 & 0 & 0 & 2 \\
Pix & 1 & 0 & 0 & 1 \\
\hline Religious Magazines & 5 & 5 & 0 & 0 \\
\hline Western Record. & 2 & 2 & 0 & 0 \\
Christian Cent. & 1 & 1 & 0 & 0 \\
Watchman Examiner & 1 & 1 & 0 & 0 \\
Missions & 1 & 1 & 0 & 0 \\
\hline
\end{tabular}


Table XVIII (continued)

Magazines Read by Letter Writers

Magazines Combined Groups Group I

"Business" Magazines

\begin{tabular}{llll}
2 & 0 & 2 & 0 \\
\hline 1 & 0 & 1 & 0 \\
1 & 0 & 1 & 0
\end{tabular}

Nation's Bus.

3

Organizational

Am. War Dads

Am. Legion Magazine

J. Daughters of the Am. Rev. I

\begin{tabular}{lll}
0 & 1 & 2 \\
\hline 0 & 1 & 0 \\
0 & 0 & 1 \\
0 & 0 & 1
\end{tabular}

\begin{tabular}{lllll}
\hline HHighbrow" & 7 & 0 & $I$ & 6 \\
\hline Atlantic MonthIy & 1 & 0 & 1 & 0 \\
New Leader & 1 & 0 & 0 & 1 \\
New Republic & 2 & 0 & 0 & 2 \\
Nation & 1 & 0 & 0 & 1 \\
Survey & 1 & 0 & 0 & 1 \\
Harper's & 1 & 0 & 0 & 1
\end{tabular}

\begin{tabular}{lllll}
\hline Miscellaneous & 6 & 3 & 0 & 3 \\
\hline Defender & 2 & 2 & 0 & 0 \\
\hline International & 1 & 1 & 0 & 0 \\
Printer's Ink & 1 & 0 & 0 & 1 \\
Freedom \& Union & 1 & 0 & 0 & 1 \\
Book of the Month Glub News & 1 & 0 & 0 & 1 \\
\hline
\end{tabular}


Table XIX

Fiction Readings of Letter Writers

Group I

\begin{tabular}{|c|c|}
\hline X.A. & Never read." \\
\hline I. W. & None \\
\hline V. I. & "Never read." \\
\hline S. G. & "Never read." \\
\hline O. Y. & 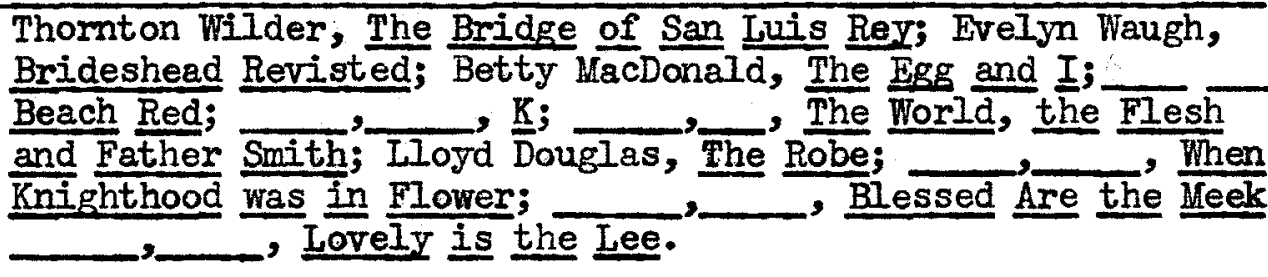 \\
\hline$\overline{\mathrm{X} \cdot \mathrm{V} \cdot}$ & $\begin{array}{l}\text { Favorite authors listed: Mark Twain, Sir Conan A. Doyle, } \\
\text { Shakespeare, Margaret Mitchell, Alexandre Dumas. }\end{array}$ \\
\hline T. $\mathrm{Y}$. & None \\
\hline T. D. & Iloyd Douglas, The Robe, Keys of the Kingdom \\
\hline U. N. & None \\
\hline 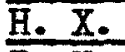 & None \\
\hline T. H. & $\begin{array}{l}\text { F. Wakeman, The Hucksters; S. Maugham, The Razor's Edge; } \\
\text { B. Schulberg, What Lakes Sammy Run; E. Goudge, Green Dolphin } \\
\text { Street; Edna Ferber, Great Son; Betty Smith, A Tree Grows in } \\
\text { Broaklyn; John Hersey, A Bell for Adano; } \\
\text { Fennigate; }\end{array}$ \\
\hline Q. S. & None \\
\hline G. G. & \\
\hline
\end{tabular}

Group II

\begin{tabular}{|c|c|}
\hline 1. V. & tion per month." \\
\hline T. $\bar{X}$. & None \\
\hline$\overline{X .} \bar{u}_{.}$ & "Poetry and the classics." \\
\hline V. N. & $\begin{array}{l}\text { Favorite authors listed: Bess S. Aldrich, Joseph C. Lincoln } \\
\text { Mildred Walker, Conrad Richter, Temple Bailey. }\end{array}$ \\
\hline S. T. & $\begin{array}{l}\text { D. Du Maurier, Hungry } \frac{\text { Hill ; K. Fearing, Exit a Dictator; }}{\text { Bjlery Queen, Ommibus; Vicki Baum, Hotel Berlin; "I read }} \\
\text { little fiction." }\end{array}$ \\
\hline U. N. 2 & None \\
\hline H. V. & $\begin{array}{l}\text { Favorite authors listed: E. Hemingway, Erskine Caldwell, } \\
\text { Jessie Stuart, Guthrie, Havighurst }\end{array}$ \\
\hline Z. Y. 2 & No timen \\
\hline
\end{tabular}


Table XIX - (continued)

V. Z. N. Frank Werfel, The Song of Bernadette; Mary E. Chase, Windswept; Mary J. Ward, The Snake Pit; Jessie Stuart, Taps for Private Tussie; Roberts, The Great Meadow; , God's Front Porch.

Q. Q. Mark Twain, Huckleberry Finn; A. Dumas, The Count of Monte Cristo; Joel Harris, Uncle Remus; Margaret Witchell, Gone with the Wind; Hervey Allen, Anthony Adverse; lists authors, James F. Cooper, O'Henry, Dickens, Walter Scott.

Q. S. None

I. Bromfield, The Farm; K. Rawlings, The Yearling; Stewart E. White, Speaking for Mrself; Centuries; $\therefore$ The Valley and Beyond.

I. S. Mary Johnson, To Have and To Hold; Victor Hugo, Les Misserables: V. Hugo, The Hunchback of Notre Dame; Nathaniel Hawthorne, Charles Dickens.

$\overline{\mathrm{X}} \cdot \overline{\mathrm{X}}$. L. Douglas, The Robe; Betty lacDonald, The Egg and I; Louise Dickinson, We Took to the Woods; in My Heart; Revelry in Boston; Bright Boy; , Launching into Glory; There's a Spot Barnabas. The Brother;

Group III

G. U. Mary J. Ward, The Snake Pit

Z. 0. S. Lewis, Kingsblood Roral; L. Hobson, Gentleman's Agreement; J. Marquand, The Late George Apley; John St einbeck, Grapes of Wrath; W. T. Hedden, The Other Room; ___ _ The Street; Norels by Upton Sinclair (2).

Z. I. E. Bellamy, Looking Backward; Sinclair Lewis, Kingsblood Royal; P. Donato, Christ in Concrete; Meyer Levin, My Father's House;

L. Hobson, Gentleman's Agreement; B. Marshall, Vespers in Vienna; Cervantes, Don Quixote.

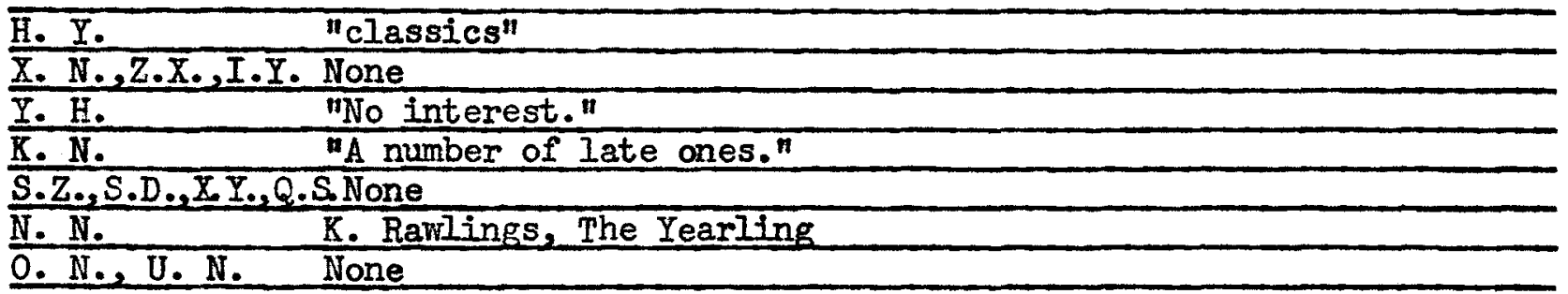


Table XX

Non-Fiction Readings

Group I

\begin{tabular}{ll}
\hline $\bar{X} \cdot$ A. & "Never read." \\
\hline I. W. V. I. & Nane \\
\hline S. G. & "Reading on Cammuism (Hate). \\
\hline O. Y. & Ernie Pyle, Brave Men; J. Hersey, Hiroshima; Maudlin, Up \\
& Front With Maudlin; R. Payne, Forever China.
\end{tabular}

X. V. Bible; Ernie Pyle's books; Ridpath, U. S. History.

T. Y. H. G. Wells, An Outline of History; V. Calverton (ed.), The Making of Man; The Federalist; S. Bemis, Diplomatic History of the U. S.; H. Gowen, A History of Religion.

T. D. None relevant to letters. Lists 10 , of which 8 are religious.

U. N. None

H. X. As He Saw It; George Morganstern, Pearl Harbor.

T. H. J. Gunther, Inside Asia, Inside USA; K. Rowen, A Yankee from Olympus; L. M. Cherme, Rest of Your Life; R. G. Swing, Preview of History; E. Snow, Red Star over China, Pattern of Soviet Power; , Total Peace.

Q. S., Q. Q. None

Group II

I. V. "Interests:-economics, statistics, sports."

Q. $Y .$, I. $\bar{X}$. None

X. M. Interests:-electricity and mathematics. The Curies.

V. N. $\quad$ B. T. Washington, Up From Slavery; Ernie Pyle's books.

S. W. C. Darinin, Origin of Species, The Descent of Man; A. Hitler, Mein Kampf; Wineider, History of Babylonia and Assyria;

A. Evans, Prehistoric Tombs of Cnossus.

U. N. 2 None

H. V. Revised New Testament; S. Maugham, The Summing Up; In incoln Steffins, Autobiography; I. Cobb, Exit Laughing; M. Eastman, The Enjoyment of Laughter; A. Link, The Return to Religion; M. Adler, How to Read a Book; R. Hilijer, First Principles of Verse; T. Clark, History of KentuckY.

V. Y. 2 "Mental health, temperance and emotional life."

V. Z. N. E. Pyle, This Is Your War; P. Van Paasen, Days of Our Years; Wainvright's Memoirs; The Unobstructed Universe. 
Table XX - Non-Fiction Readings (continued)

\begin{tabular}{|c|c|}
\hline Q. Q. & $\begin{array}{l}\text { Favorite authors and their subjects listed: H. E. Fosdick, } \\
\text { religion; R. Babson, economics; Iincoln (?), biography; } \\
\text { W. James, psychology; Burroughs, nature; Van Dyke, humor. }\end{array}$ \\
\hline$\overline{\text { Z. S. }}$ & Bible \\
\hline Q. D. & $\begin{array}{l}\text { C. Bowers, The Tragic Era; L. Lawes, 20,000 Years in Sing Sing; } \\
\text { Beneath Tropic Seas; }\end{array}$ \\
\hline$\frac{I_{\cdot} S_{0}}{\bar{X} \cdot \overline{X_{0}}}$ & $\begin{array}{l}\text { "Political Science, Economics and Sociology." } \\
\text { K. Bowen, Yankee from Olympus; E. Amall, The Shore Dimly Seen; } \\
\text { W. St egner, One America; } \\
\text { Lamb and Grey Falcon; 'Life of Jackson; } \overline{\text { The Raven; }}\end{array}$ \\
\hline
\end{tabular}

Group III

G. U. B. Barton, What Can a Man Believe; Dunnin, What's On Your Mind; B. King, The Conquest of Fear; Adam Beck, The Story of Oriental Philosophy; Rose Daw, Mayan Mysteries; Rose Dawn, The Sermon on the Lount; Dr. W. W. Bauer, 1000 Heglth Questions Answered.

Z. 0 . J. Gunther, Inside U.S.A.; Geo. R. St ewart, Man, An Autobiography; R. Benedict and G. Weltfish, Races of Mankind; Beveridge on Unemployment; J. Fischer, Why They Behave Like Russians; C. McWilliams, Factories in the Field; F. Perkins, Roosevelt.

Z. I. B. Schrieke, Alien Americans; G. Ifyrdal, An American Dilemma; Dubois, The World and Africa; B. Crum, Behind the Silken Gurtain; J. Gunther, Inside U.S.A.; from Spain; Why Men Hate; Henry George. Action for Unity; Treasons Peace;

H. $\mathrm{Y}$. "prohibition propaganda."

X. N. Indian Fights and Flghters; $E$. Coulter, History of the South.

Z. $\bar{X}$. H. Shumway, Bernard Baruch

I. Y., Y. H. None S. Z. Lincoln Reader

K. N. Sociology. G. Myrdal, An American Dilemma

S. D. MO time." 
Table XX - Non-Fiction Readings (continued)

X.Y.

Q. S.

N. N.

0. N.
"Larly americana."

Louis Bromfield, Pleasant Valley

None

M. Adler, How to Think About War and Peace; Harvard Report, General Education in a Free Society; Davies, The Faith of an Unrepentant Liberali Woodward, Tom Paine: America's Godfather; Lin Yutang, Betwreen Laughter and Tears; C. Bowen, Yankee from Olympus; Reves, The Anatomy of Peace; Liebman, Peace of Mind; W. Willkie, one World; M. Ernst, The First Freedom.

U. H. Elizabeth Browning's poems. 
Table XXI

Distribution by Field and by Topic of the Letters Written by Forty-four Writers June 1, 1946 - May 21, 1947 .

A. Intermational and Foreign Affairs

(1) The Soviet Union

$18 \frac{1}{2}$

(2) Atom Bomb and Peace

12

(3) The Refugee Problem

(4) The U. N. 0.

(5) Spanish Civil War

(6) Great Britain

(7) Greece-Turkey

(8) Nuemberg Trials

(9) Palestine

B. National Affairs

(1) Organized Labor

(2) 0.P.A. - Cost of Iiving

(3) The New Deal

(4) So. Politics and Race

(5) General-Governmental

(6) Republican Party

(7) Big Business

(8) The Lilienthal Appt.

(9) Henry A. Wallace

(10) Communists-J.S.A.

(II) Presidential Succession

(12) Non-roting

(13) The "Truman Purge"

(14) Lower Voting age to 18

(1) The New Constitution

(2) The State Dem. Party

(3) State Pride

(4) Education in Kentucky

$13 \frac{1}{6}$

(5) The State Rep. Party

(6) General-State Govt.

(7) Labor in the State

(8) Committee for Kentucky

(9) Amicable Intra-St. Relations 
D. Local Affairs

(1) City Government-General
(2) General-Praise or Blame
(3) Local Music
(4) Public Ownership-L.G. \& E.
(5) Local Gambling and Liquor
(6) Flood Wall
(7) Local Labor Organizations
(8) The Courier Journal
(9) Municipal Bridge

12

11

7

5

2

2

2

$\frac{1}{1}$

E. General

(1) Gambling and Liquor
(2) Persons
(3) Miscellaneous
(4) Army Veterans
(5) "Booster"
(6) Morality"
(7) Religion
(8) Catholicism (explanatory)
(9) Parochial Schools
(10) General-Governmental
(11) Anti-Dog
(12) Iocal Crime
(13) Iiberals and Conservatives
(14) Informational (DDr)
(15) Mercy Killing
(16) Freight Rate Differentials

(I) Gambling and Iiquor

22

15

10

8

8

8

6

4

4

3

1

A Note on the above, with respect to classification.

It is acmitted that the field and topical classification resorted to in this section is arbitrary, considering that a considerable number of the letters cut across field and topical classifications.

The writer classified letters according to what seemed to him to be their logical place, judging them by their emphases and content. At the same time an effort was made to keep the number of topical and field headings at a minimum in order to avoid the confusion and analytical difficulties that would result from a more precise and detailed cataloging of the subject matters of the letters. In sone fow cases it was deemed necessary to classify letters under two topic headings, considering the relative equality of content and emphasis upon two of the listed topics. 
81.

As one might expect, the greater difficulty was encountered in the topical classification of letters, a more discriminating operation than classification according to field. The difficulty was increased by a tendency on the part of quite a few writers to ramble and to use arguments that had little or no logical connection with the point of major emphasis and concern, but which, in the aggregate, take up considerable portions of some letters.

Under National, State, and Local Affairs a classification, "GeneralGovernmental," is used. This is a "catch-all" and includes letters written on subjects of restricted public interest, such as legislative procedure, etc. If classified more specifically in the outline these letters would all demand separate topical classification.

It will be noticed that the topic "Labor" appears under National, State, and Local Affairs. In the case of the latter two fields the letters included in them restrict themselves to discussions of labor as either a state or local problem. 